\title{
Role of non-classical polymerases and SUMO PCNA dependent mechanisms in the maintenance of genome stability
}

Ph.D Thesis

\section{Himabindu GALI}

Supervisor: Dr. Lajos Haracska

Doctoral school of biology

University of Szeged

Institute of Genetics

Biological Research Center of the Hungarian Academy of Sciences 


\section{Table of contents}

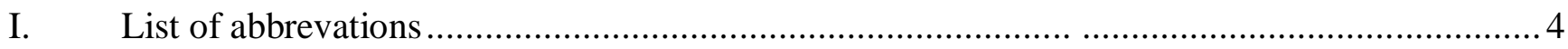

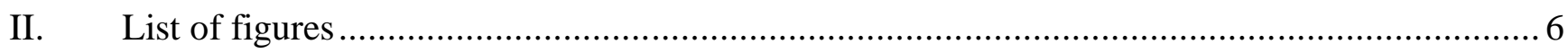

1.0 Introduction

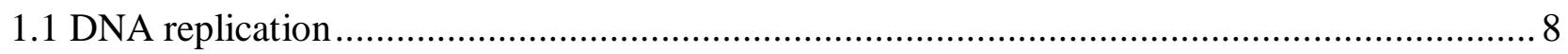

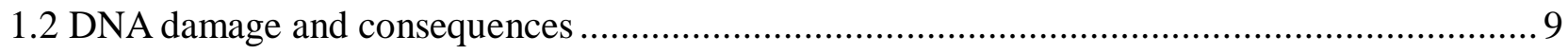

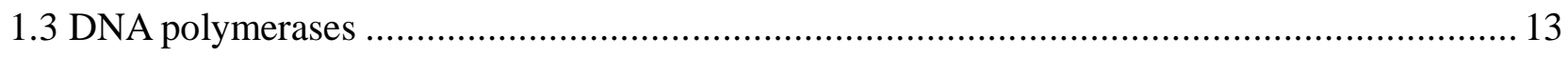

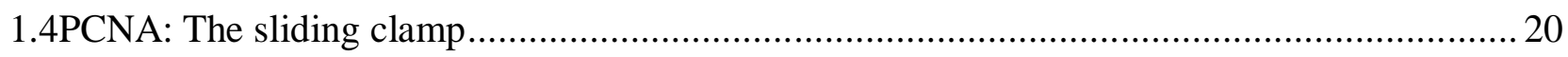

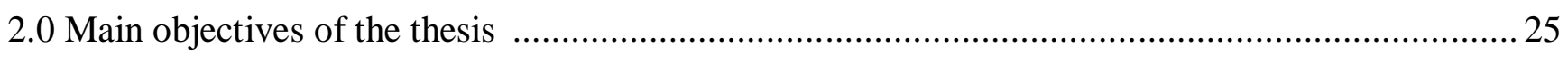

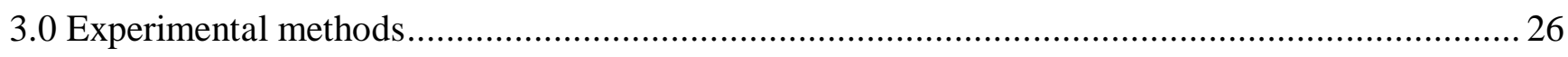

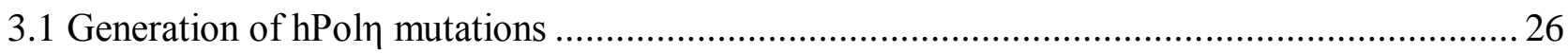

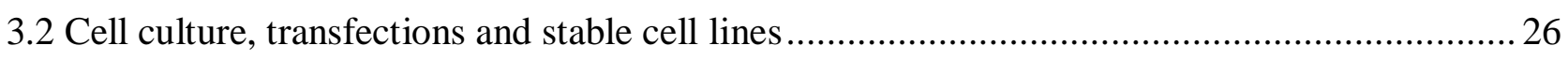

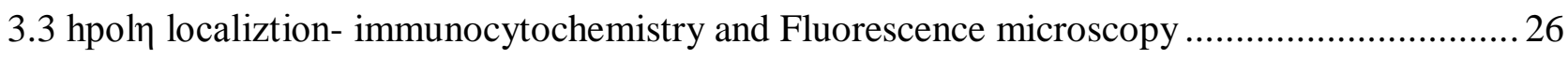

3.4 Isolation, immortalization and culturing of Rev $1^{\mathrm{B} / \mathrm{B}}, \operatorname{Rev}^{-{ }^{-/}}$, Rev $3^{-/-}$MEFs............................. 27

3.5 Labeling of replicating DNA and generation and visualization of DNA fibers........................ 27

3.6 Generation and expression of constructs for PCNA SUMOylation..........................................2 28

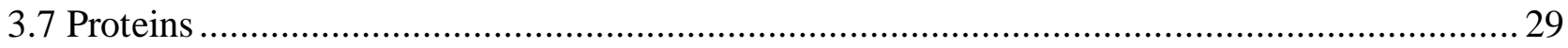

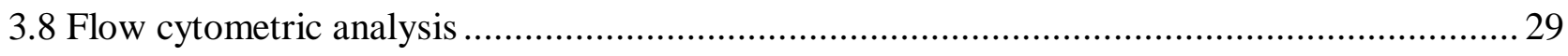

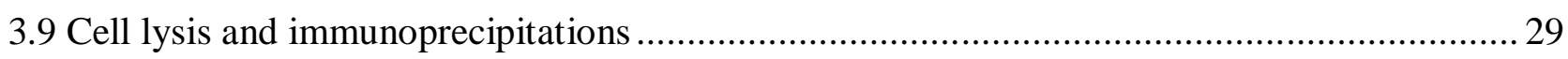

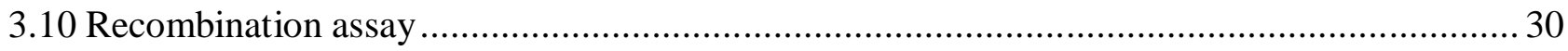

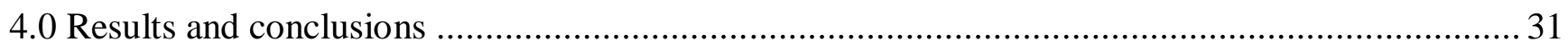

4.1 Roles of PCNA-binding and ubiquitin-binding domains in human DNA polymerase in

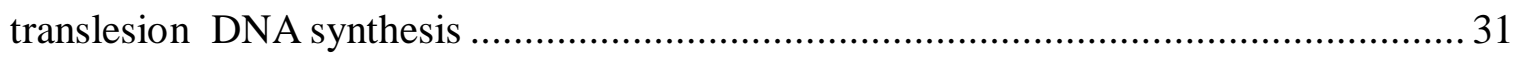

4.1.1 Identification of an additional PCNA-Binding PIP Motif in hPol $\eta$............................... 31

4.1.2 Requirement of PCNA-Binding PIP Domains for Accumulation of hPoln in Replication

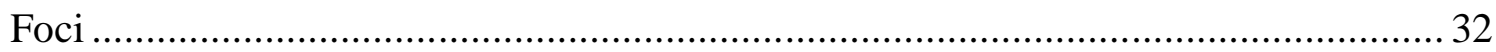

4.1.3 Accumulation of hPol $\eta$ UBZ Mutant Proteins in Replication Foci............................... 33 
4.2 Regulatory roles of Rev1 in DNA damage bypass....................................................... 34

4.2.1 The Rev1 BRCT domain is essential for an early pathway for bypassing UV-damaged ....

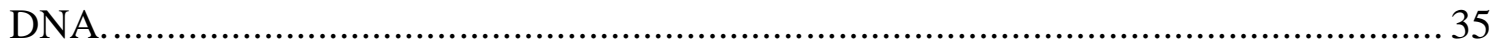

4.3 Role of Polymerase Zeta in the bypass of UV induced DNA lesions ................................. 37

4.3.1 Mammalian Rev3 is not essential for early translesion synthesis ............................ 38

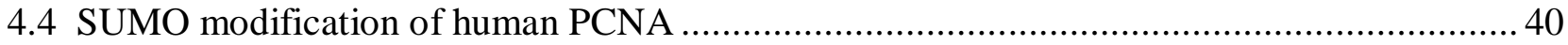

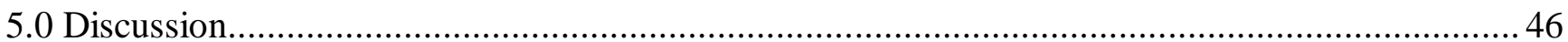

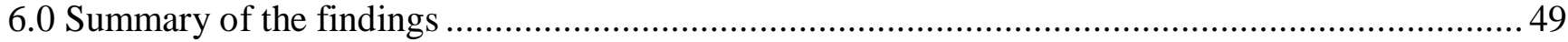

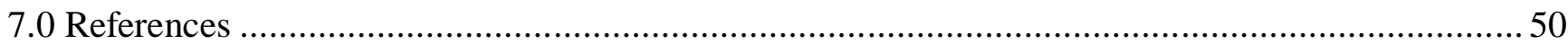

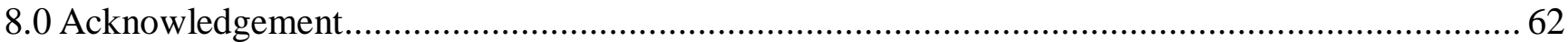

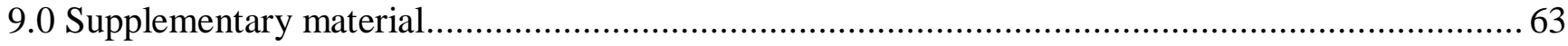

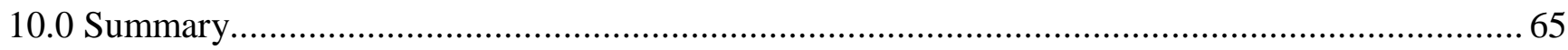

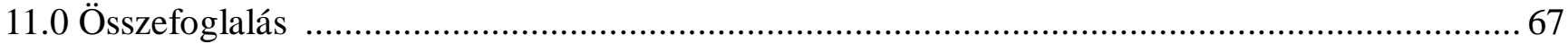




\section{List of Abbreviations}

AP sites: apurinic/apyrimidinic

ATP: Adenosine triphosphate

BrdU: Bromo deoxy uridine

BER: Base excision repair

BPDE: Benzopyrene-7,8-Diol-9,10-Epoxide

BRCT: BRCA1 C-terminus

BSA: Bovine serum albumin

CPD: Cyclobutane pyrimidine dimer

DAPI: 4', 6-diamidino-2-phenylindole

DNA: Deoxyribonucleic acid

DSB: Double strand break

GFP: Green fluorescent protein

GST: Glutathione $S$-transferase

HLTF: Helicase like transcription factor

HJ : Holliday Junction

HR: Homologous Recombination

IdU: Iodo deoxy uridine

ISCeI: Homing endonuclease

IDCL: Inter domain connecting loop

MEF: Mouse embryonic fibroblasts

MMR: Miss match repair

MMS: Methyl methane sulphonate

MMS2: Methyl methane sulphonate sensitivity 2

NER: Nucleotide excision repair

NHEJ: Non Homologous End Joining

PAD: Polymerase associated domain

PCNA: Proliferating cell nuclear antigen

PDB: Protein data base

PIAS: Protein inhibitor of activated STAT

PIP: PCNA interacting peptide

Pol: Polymerase

PRR: Post replication repair 
RAD: Radiation sensitivity protein

REV: Reversionless

RFC: Replication factor $\mathrm{C}$ protein

RNA: Ribonucleic acid

RPA: Replication protein A

SHPRH: SNF2 histone linker PHD RING helicase

SSB: Single-strand binding protein

SRS2: Suppressor of RAD6-2

STAT: Signal transducer and activator of transcription

SUMO: Small ubiquitin like modifier

SV40: Simian virus 40

TLS: Translesion synthesis

UBC: Ubiquitin carrier protein

UBD: Ubiquitin binding domain

UBZ: Ubiquitin binding zinc finger

UV: Ultraviolet

WT: Wild type 


\section{List of figures}

Figure 1. Schematic representation of eukaryotic DNA replication fork. ..................................... 9

Figure 2. DNA damage, repair mechanisms and consequences. ......................................... 11

Figure 3. The Rad6-Rad18 dependent damage tolerance pathway.............................................. 13

Figure 4. Schematic representation of the crystal structure of a high fidelity polymerase and a

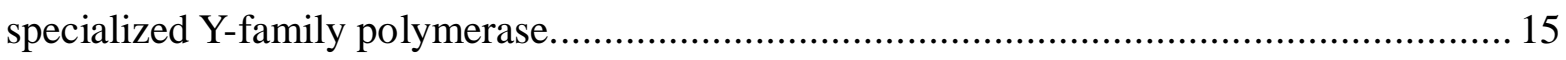

Figure 5. X-ray crystal structure of wild type yeast PCNA from the front and side view.................22

Figure 6. A model established in S.cerevisiae for the role of PCNA covalent modifications in DNA

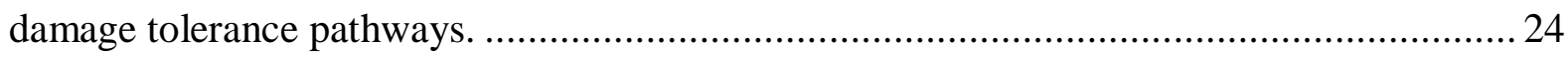

Figure 7. Schematic representation of the domain structure of human polymerase eta. ...................31

Figure 8. Requirement of PIP domains of hPol $\eta$ for its accumulation in replication foci................. 32

Figure 9. UBZ mutant $\mathrm{hPol} \eta$ proteins accmulate in replication foci........................................ 33

Figure 10. Schematic representation of replication labeling and representative replication forks during ongoing and stalled replication. ............................................................... 34

Figure 11. Replication rate in undamaged wild type and Rev1 mutant MEFs.............................. 35

Figure 12. Representative set of DNA fibers of wild type and Rev1 mutant MEFs...................... 35

Figure 13. Average ratio of IdU: BrdU in wild type and Rev1 mutant MEFs and mutant MEFs complemented with mouse Rev1. .................................................................... 36

Figure 14. length of replicating forks during BrdU labeling in Wild type and Rev1 mutant MEFs ..... 36

Figure 15. Schematic representation of replication labeling and representative replication forks during ongoing and stalled replication. 37

Figure 16. Representative set of DNA fibers from wild type and Rev $3^{-/-}$MEFs ........................... 37

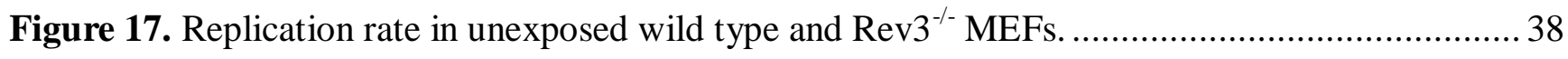

Figure 18. Length of replication forks during BrdU labeling in wild type and Rev3 ${ }^{-/-}$MEFs............ 38 
Figure 19. Distribution of percentage of replication forks at corresponding IdU:BrdU ratios of wild type and Rev3 mutant MEFs.

Figure 20. In vivo SUMO modification of human PCNA. .................................................. 40

Figure 21. Effect of K164 R mutation in the SUMO modification of human PCNA..................... 41

Figure 22. In vitro SUMO modification of human PCNA ...................................................... 41

Figure 23. In vitro SUMOylation in the absence or presence of PIAS proteins. ........................... 41

Figure 24. Structure of human PCNA from the front and side views with surface lysine residues. ..... 42

Figure 25. In vitro SUMOylation of wild type and lysine mutants of human PCNA. ..................... 42

Figure 26. Comparison of In vitro SUMOylation and ubiquitylation reactions............................. 43

Figure 27. (A) Schematic representation of the fusion of SUMO1 at the C-terminus of a FLAG-tagged PCNA and the control vectors. (B) Purified human PCNA and human PCNA-SUMO1 fusion proteins were analyzed.......................................... 43

Figure 28. PCNA-SUMO1 fusion protein is efficient in ubiquitylation reaction............................ 44

Figure 29. Immunoblot analysis of the expression of PCNA-SUMO1 fusion protein and control proteins as compared to the endogenous PCNA. ............................................... 44

Figure 30. Immunolocalization of PCNA-SUMO1 protein. ............................................. 44

Figure 31. Flow cytometric analysis of the cell cycle distribution of cells expressing PCNA-SUMO1

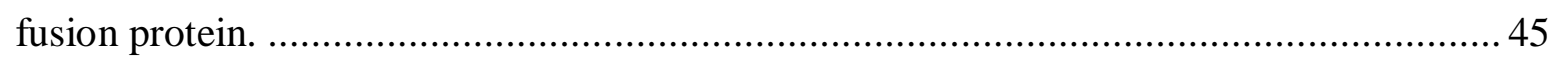

Figure 32. Effect of PCNA-SUMO1 fusion protein on Homologous recombination frequency ......... 45

Supplementary Figure 1. Distribution of percentages of replication forks at corresponding IdU: BrdU ratios of Wild-type and Rev1 mutant MEFs. 


\section{Introduction}

\subsection{DNA replication}

DNA replication is a highly organized process. It requires the co-operation of many proteins at the replication fork, collectively known as the replisome which ensure fidelity, processivity and timing (Reviewed by Davey et al 2000). Eukaryotic DNA replication starts from many points on the chromosome known as origins of replication and can be fired once during each cell division. DNA replication involves moving forks of a replication bubble composed of leading and lagging strand DNA synthesis in the 5' to 3 ' direction. DNA replication requires efficient and processive DNA polymerases with specialized functions like Pol $\alpha$, Pol $\delta$, Pol $\varepsilon$ (Johnson et al 1985; Morrison et al 1990). DNA synthesis is primed by the formation of RNA primers. DNA replication is initiated by Pol $\alpha$ (primase) which synthesizes the RNA primer and remains attached to the primer as well as to the single-stranded DNA binding protein RPA (Hubscher et al 2002). RPAs bind to single-stranded DNA and protect DNA from nuclease activity (Wold, 1997). Pola synthesizes an RNA/DNA hybrid of about 10 nucleotides followed by 20-30 more of only DNA. After synthesis of initial 30-40 bases a pol switch occurs and the resulting primer-template can then be elongated by either pol $\delta$ or pol $\varepsilon$ (Burgers 1998). In yeast, pol $\delta$ is composed of three subunits and is responsible for lagging strand synthesis and Okazaki fragment maturation (Kunkel and Burgers 2008; Burgers and Gerik 1998). In contrast, pol $\varepsilon$ is responsible for the leading strand synthesis (Waga et al 1994; Stucki et al 2001; Kunkel and Burgers 2008; Pursell et al 2007; Stephanie et al 2008). These DNA polymerases require a processivity factor known as the sliding clamp (PCNA in eukaryotes) (Prelich et al 1987; Chilokova et al 2007). PCNA encircles DNA and tethers Pol $\delta$ to the DNA via its C-terminal tail (Ducoux et al 2001). PCNA is loaded onto DNA by means of the clamp loader which is known as the RFC (Replication Factor C) (Yoder and Burgers 1991; Burgers and Yoder 1993). RFC opens the circular molecule of PCNA and closes it around DNA (Yao et al 2006; Mossi et al 1998). Lagging strand DNA synthesis creates a challenge in which several newly synthesized 
DNA strands, known as okazaki fragments, must be processed and joined together (Pringent et al 1994). In addition several proteins are required at the replisome for DNA repair and proper cell cycle control. A typical eukaryotic DNA replication fork is represented in Figure 1.

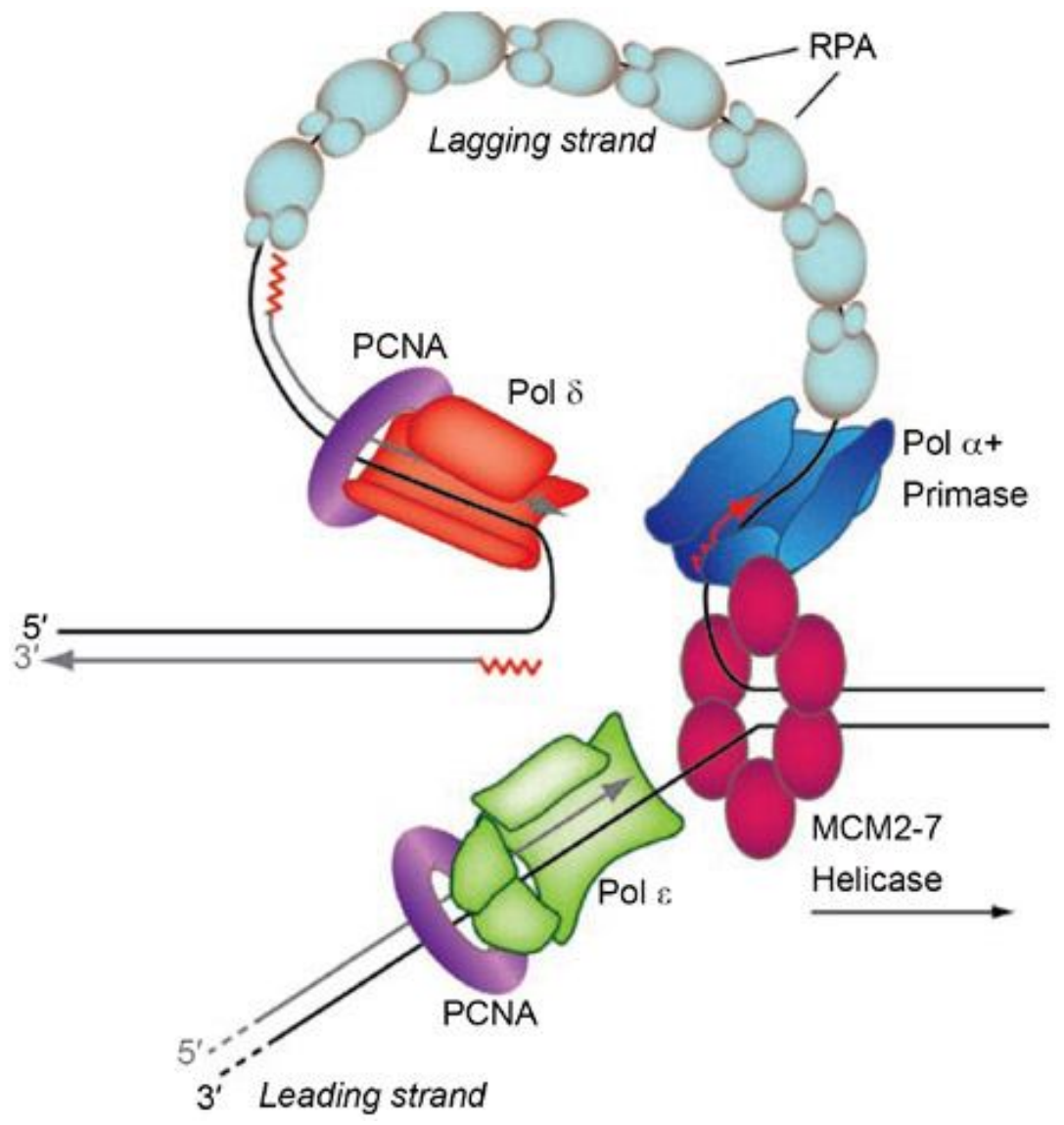

Figure 1. Schematic representation of the eukaryotic DNA replication fork based on the SV40 in vitro DNA replication model (adapted from Burgers 1998).

\subsection{DNA Damage and consequences}

Cellular DNA of living organisms is constantly exposed to genotoxic agents (both exogenous and endogenous) resulting in damage to DNA. Exogenous sources include ultraviolet radiation (UV), ionizing radiation, and chemical agents resulting in both single and double stranded breaks, as well as many types of base lesions. These DNA breaks are a major block to DNA replication and, if left 
unrepaired, can ultimately lead to genomic rearrangement or cell death. Endogenous sources are the predominate means by which DNA is damaged in the cell under normal conditions. Endogenously generated lesions are mainly produced through hydrolytic and oxidative reactions, which are the consequences of the cellular environment and byproducts of cellular processes. It has been estimated that human cells generate 10,000 abasic sites a day, which can result in mutations or stalling of the replication fork if left unrepaired (Lindahl 1993; Barnes and Lindahl 2004; Lindahl and Barnes 2000). With so many types of DNA lesions occurring at such a high frequency, the cell has developed multiple biological responses to DNA damage. These processes can be divided into two main categories: DNA repair and DNA damage tolerance (Figure 2).

\subsubsection{DNA Repair}

DNA repair is a cellular response to DNA damage that results in the restoration of the normal nucleotide sequence and DNA structure. Cells have developed mechanisms to repair all possible forms of DNA damage (Friedberg et al 1995; Schärer 2003). Cells utilize the following major DNA repair pathways: Direct reversal by photolyase (Sancar et al 1996a); Homologous recombination (HRR) (Heyer 2004; Krogh and Symington 2004) ; Non-homologous End Joining (NHEJ) (Weterings et al 2008); Nucleotide Excision Repair (NER) (Sancar et al 1996a; Fousteri \& Mullenders 2008) ; Base Excision Repair (BER) (Sancar et al 1996a; Parikh et al 1998); Mismatch repair (MMR) (Flores-Rozas et al 2000; Longley et al 1997; Ramilo et al 2002) (Figure 2). These DNA repair pathways are highly conserved from bacteria to mammals. In the vast majority of cases, proteins that carry out these repair pathways are conserved in structure and function. Defects in these pathways would lead to an accumulation of mutations in genomic DNA so as to increase the frequencies of mutagenesis and cell death. 

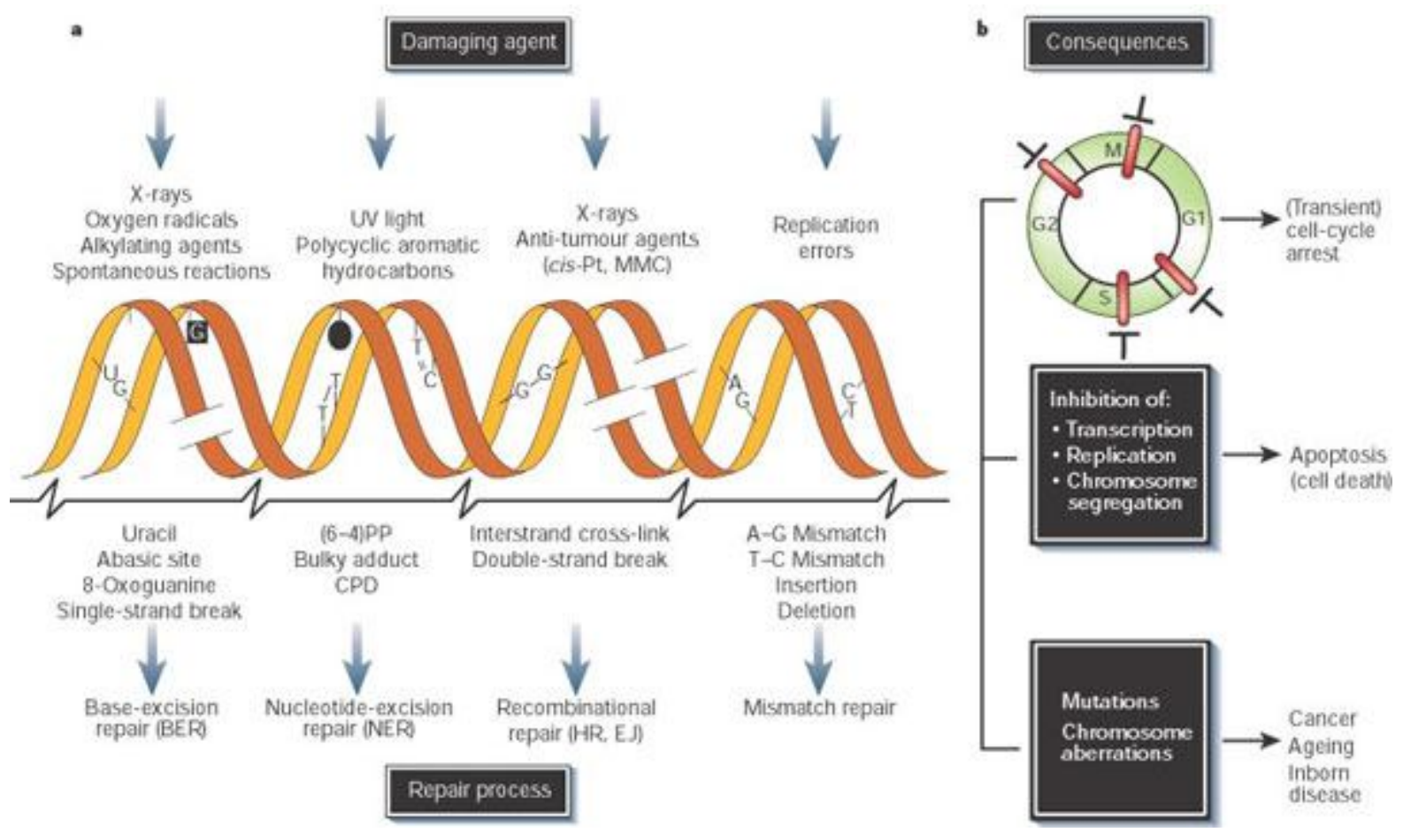

Figure 2. DNA damage, repair mechanisms, and consequences. (a) Common DNA damaging agents (top), examples of DNA lesions induced by these agents (middle), and the most relevant DNA repair mechanism responsible for the removal of the lesions (bottom). (b) Acute effects of DNA damage on cell cycle progression, leading to transient arrest in the G1, S, G2, and M phases (top) and on DNA metabolism (middle). Long-term consequences of DNA injury (bottom) include permanent changes in the DNA sequence (point mutations affecting single genes or chromosome aberrations that may involve multiple genes) and their biological effects. Abbreviations: cis-Pt and MMC, cisplatin and mitomycin C, respectively (both DNA-cross-linking agents); (64)PP and CPD, 6-4 photoproduct and cyclobutane pyrimidine dimer, respectively (both induced by UV light); BER and NER, base- and nucleotide-excision repair, respectively; HR, homologous recombination; EJ, end joining. (Hoeijmakers, J. H. J. Genome maintenance mechanisms for preventing cancer. )

\subsubsection{DNA damage tolerance}

Even with multiple pathways to repair DNA damage there will persist some amount of damage that must be tolerated during DNA replication. This process of coping with DNA damage is referred to as the DNA damage tolerance pathway. This pathway is as biologically important as the DNA repair pathways. During DNA damage tolerance, the lesion is bypassed and left unrepaired in hopes of it being fixed in subsequent stages of the cell cycle by the DNA repair machinery described above (Budzowska and 
kanaar 2009). This temporary bypass and tolerance of a DNA lesion often comes at a cost. There is an increased mutation rate at the lesion site due to the error-prone nature of this process (McCulloch and Kunkel 2008). The predominant mechanism of DNA damage tolerance is translesion synthesis. Translesion synthesis is the replicative bypass of DNA damage by non-classical DNA polymerase. This process involves the direct incorporation of nucleotides across from a DNA lesion, which blocks DNA replication by classical polymerases that are unable to accommodate the lesion in their active site. This process is error-prone because the polymerases responsible for translesion synthesis have a reduced fidelity of nucleotide incorporation, a property that allows them to accommodate the structural distortions caused by various types of DNA lesions (Prakash et al 2005). In fact, replication errors associated with translesion synthesis are believed to be responsible for almost all DNA damage-induced mutations (Guo et al 2009). The non-classical polymerases involved in translesion synthesis in eukaryotes are polymerase $\eta$, polymerase 1 , polymerase $\zeta$, polymerase $\kappa$, and the Rev1 protein. In vitro studies have provided valuable insight into the mechanisms of each of these polymerases (Washington et al 2009). These studies have shown that each of these polymerases bypass DNA lesions in a unique manner, but each polymerase has a reduced fidelity compared to classical polymerases (McCulloch and Kunkel 2008; Washington et al 2009). To employ these non-classical polymerases, the stalled classical polymerase at the site of DNA damage must be exchanged for a non-classical polymerase. The non-classical polymerase will then bypass the damage and a second exchange will occur between the non-classical and the classical polymerase. This switching event is believed to be mediated by replication accessory factors at the replication fork such as PCNA (de Saro 2009; Lehmann et al 2007). All Y-family polymerase homologs are members of the Rad6 epistasis group. Rad6 protein functions as an E2 ubiquitinconjugating enzyme, which interacts with the E3 ligase Rad18. The concerted actions of Rad6 and Rad18 are required for the monoubiquitination of Lys164 of PCNA in response to stalled replication caused by DNA damage (Friedberg, Lehmann et al. 2005). 


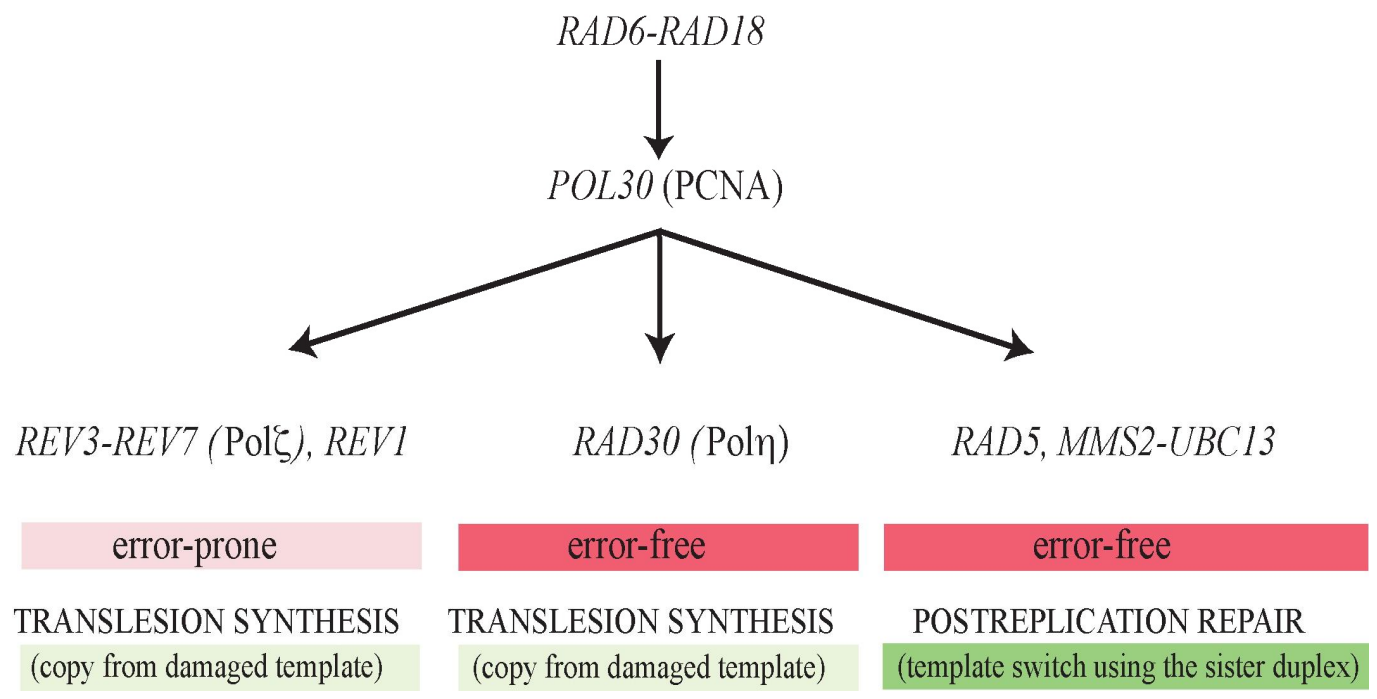

Figure 3. The Rad6-Rad18 dependent damage tolerance pathway. The Rad6-Rad18 governs at least three ways of replication of UV-damaged DNA through the ubiquitylation of PCNA: 1, the Rev3, Rev7 and Rev1 dependent error-prone translesion synthesis; 2, the Rad30dependent error-free translesion DNA synthesis; 3, the Rad5 and Mms2-Ubc13dependent error-free postreplication repair pathway.

\subsection{DNA Polymerases}

The eukaryotic cell utilizes 14 to 16 polymerases to conduct the various pathways of DNA metabolism. There are currently six major families of DNA polymerases based on amino acid sequence similarity: A, B, C, D, X, and Y (Burgers et al 2001). The A family is composed of prokaryotic polymerases involved in both DNA replication (T7 polymerase) and repair (E.coli polI) (O’Donnell 2006). The B family is composed of the major eukaryotic replicative polymerases, Pol $\alpha$, Pol $\varepsilon$, and Pol $\delta$ (Garg and Burgers 2005). The B family also contains polymerase $\zeta$ which is involved in lesion bypass synthesis and primer extension (Guo et al 2001). The C family is composed of prokaryotic replicative polymerases (E. coli pol III) (O’Donnell 2006). The D family is composed of the Archea replicative polymerases. The X family is composed of polymerases involved in base excision repair (polymerase $\beta$ ) and nonhomologous end joining (polymerase $\mu$ and $\lambda$ ) (Sobol and Wilson 2001). The Y family is composed of polymerases that are unique in their low fidelity and their ability to replicate through DNA lesions (Guo et al 2009). With 
the exception of Pol $\zeta$, the polymerases involved in translesion synthesis are all members of the Y family.

\subsubsection{Classical polymerases}

Classical polymerases are those that replicate through normal non-damaged DNA and are involved in bulk genome replication and repair. In eukaryotes, the three DNA polymerases responsible for bulk genome replication belong to the $\mathrm{B}$ family and are Pol $\alpha$, Pol $\delta$, and Pol $\varepsilon$. These polymerases are all thought to act together during DNA fork progression with the other accessory proteins and have already been described above in the DNA replication section. Both Pol $\delta$ and Pol $\varepsilon$ contain a 3' to 5' proofreading exonuclease activity that enhances their fidelity by 10-60 fold (McCulloch and Kunkel 2008). This exonuclease domain detects and removes any incorrect nucleotides allowing a correct one to be subsequently incorporated. A hallmark characteristic of classical DNA polymerases is their inherently high fidelity, even in the absence of the proofreading exonuclease domain. X-ray crystal structure of the classical polymerases, most recently Pol $\delta$, have shown that the high fidelity is achieved by the active site pocket accommodating only the correct Watson-Crick base pair (Swan et al 2009). Mismatches stall polymerases through unfavorable interactions between the mismatch and the polymerase active site (Johnson and Beese 2004).

\subsubsection{Non- Classical polymerases}

Non-classical polymerases are those that are able to efficiently bypass damaged DNA. These polymerases are not involved in bulk genome replication and are utilized specifically during translesion synthesis to bypass lesions that block classical polymerases. The eukaryotic non-classical polymerases involved in translesion synthesis are polymerase $\zeta$, polymerase $\eta$, polymerase 1 , polymerase $\kappa$, and the Rev1 protein (Prakash et al 2005). These polymerases are all members of the Y family, except Pol $\zeta$ 
which is a B family member. Pol $\eta$ is able to bypass UV photoproducts (Washington et al 2000). Pol 1 and Rev1 both function as inserters, incorporating directly across from a DNA lesion, such as abasic sites and 8-oxo-guanines (Washington et al 2004; Haracska et al 2001d; Nair et al 2005). Pol $\kappa$ is believed to be involved in bypassing adducts on the N2 position of guanine, such as benzo[a]pyrene guanine (Ogi et al 2002, Takenaka et al 2006, Avkin et al 2004). Furthermore, Pol $\kappa$ and Pol $\zeta$ are efficient extenders from DNA lesions (Li et al 2004; Washington et al 2004a; Washington et al 2002; Haracska et al 2002; Haracska et al 2003). The major characteristic of these non-classical polymerases is their reduced fidelity compared to the classical polymerases and the lack of a proofreading domain (Washington et al 2000; Washington et al 1999). Structural studies have shown that the lowered fidelity for the Y family polymerases comes from a reduced geometric selectivity at the active site (Trincao et al 2001; Nair et al 2005; Lone et al 2007; Nair et al 2004). This results from the active site being more open and solvent accessible than the more accurate classical polymerases (Figure 4). This open active site is the basis for the ability of these non-classical polymerases to bypass DNA damage, because the active site can accommodate both the DNA lesion and any distortion to helix geometry. While this is beneficial for lesion bypass it also leads to an increase in the error rate (Washington et al 2009). Therefore, the nonclassical DNA polymerases are generally considered to be error-prone.

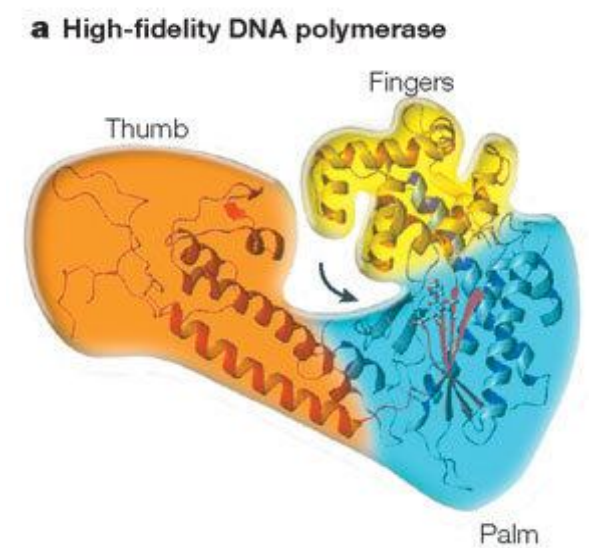

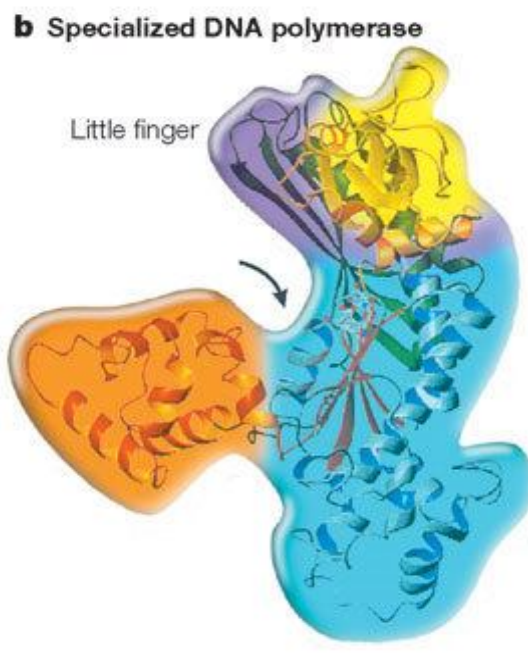

Figure 4. Schematic representation of the crystal structures of a high fidelity DNA polymerase and a specialized Y-family DNA polymerase. Thumb (orange), Palm (blue), Fingers (yellow) are present in both polymerases. The relaxed fidelity of the specialized polymerases is thought to be provided by an additional little finger (purple) (adapted from Friedberg 2005) 
All non-classical polymerases have been shown to interact with Ub-PCNA at stalled replication forks during translesion synthesis. This interaction is dependent on at least two interactions: the non-classical polymerase PIP motif to the IDCL of PCNA, and the ubiquitin-binding domain of the non-classical polymerase to the ubiquitin moiety on PCNA. The PIP motif is believed to provide a basal binding affinity between PCNA and the non-classical polymerases and is essential for the PCNA-polymerase interaction, as discussed above. The ubiquitin-binding domains are located in almost all non-classical polymerases and are involved in recognizing the ubiquitinated form of PCNA and facilitating the polymerase switch during translesion synthesis9 (Bienko et al 2005).

\subsubsection{DNA polymerase Eta (Pol $\eta)$}

DNA polymerase eta (Pol $\eta$ ) is encoded by the RAD30 gene and can efficiently and accurately bypass UV-induced DNA lesions, such as thymine-thymine dimmers (Washington et al 2000; Yu et al 2001; Johnson et al 1999; McDonald et al 1997; Roush et al 1998)7. The loss of Pol $\eta$ in humans results in the genetic disorder xeroderma pigmentosum variant form (XPV), which is characterized by an increased sensitivity to UV radiation and susceptibility to skin cancers (Masutani et al 1999; Johnson et al 1999). The increase in mutagenesis is believed to occur because the absence of Pol $\eta$ allows for the other even more mutagenic non-classical polymerases, Pol $\zeta$ and Pol $\imath$, to bypass the UV lesions. Similar results were also observed in yeast with the loss of poln resulting in a greater sensitivity to UV irradiation and an increase in mutagenesis (McDonald et al 1997; Roush et al 1998). Furthermore, it was shown that the Rad30 transcript is induced $\sim 3.5$-fold in response to DNA damage by UV-irradiation in higher eukaryotes (Pabla et al 2007; Skoneczna et al 2007). UV-induced lesions are not the only type of DNA damage Pol $\eta$ has been implicated in bypassing. Work in human cells has shown that pol $\eta$ accurately bypasses 8-oxo-guanine (8-oxo-G) lesions and cisplatin GpG adducts (Bassett et al 2004; Lee et al 2008). Together these in vivo studies indicate an important role of poln in the replicative bypass of various DNA lesions. 
The Pol $\eta \mathrm{UBZ}$ motif is a $\mathrm{C} 2 \mathrm{H} 2$ ubiquitin-binding zinc finger located between the catalytic domain of Pol $\eta$ and the PIP motif at the extreme C-terminus. In vivo studies determined that the UBZ motif is required for Pol $\eta$ recruitment to replication factories and UV survivability (Bienko et al 2005). Further localization studies determined that Pol $\eta$ localizes to these replication factories specifically with UbPCNA and this localization is enhanced by the UBZ motif (Parker et al 2007; Plosky et al 2006). These results highlight the importance of the non-catalyticUBZ structural element involved in the Pol $\eta$ and UbPCNA interaction.

\subsubsection{DNA polymerase Iota (Pol t)}

Pol $\mathrm{l}$ is a Y-family polymerase, called as Rad30b because of its high homology to the Rad30 branch of S. cerevisiae (Friedberg et al 2005). Pol $\mathrm{l}$ is a paralog of Pol $\eta$, with homologs identified in mice, and fruit flies. Unlike other Y-family polymerases, Pol 1 does not have structural homologs in bacteria, yeast, or nematodes. Pol $\mathrm{l}$ is highly error-prone on undamaged templates, incorporating dGMP opposite thymine more frequently than dAMP in a manner that violates Watson-Crick base pairing (Zhang et al 2000). In addition, Pol $\mathrm{l}$ is capable of performing insertions opposite highly distorting or non-instructional lesions in vitro, such as [6-4]-photoproducts and abasic sites, although Pol $\mathrm{\imath}$ has not been shown to possess any capacity for extension beyond these insertion events (Johnson et al 2000). A role for Pol 1 in UVradiation damage bypass has been inferred from the observation that Pol 1 colocalizes with the DNA replication machinery in response to UV-radiation in a Pol $\eta$-dependent manner (Kannouche et al 2002). Much like other TLS polymerases, Pol 1 physically interacts with Rev1 in mice and humans, as well the replication factor PCNA (Ohashi et al 2004; Tissier et al 2004; Haracska et al 2005; Guo et al 2006). In vitro, human Pol $\mathfrak{\imath}$ has been shown to function in DNA damage bypass together with Pol $\zeta$, whereby Pol $\imath$ performs the insertion event opposite DNA lesions while Pol $\zeta$ acts at the subsequent step of extending from them. These observations suggest a potential functional relationship between these polymerases in 
vivo (Johnson, Washington et al 2000). The biological significance of these interactions and the mechanism by which they function in vivo requires further investigation.

\subsubsection{DNA polymerase Kappa (Pol к)}

DNA polymerase kappa (Pol $\kappa / \mathrm{Dinb})$ is the only member of the Y-family of DNA polymerases conserved in all kingdoms of life, from bacteria to humans (Gerlach et al 1999). Despite its broad conservation, Pol $\kappa$ is not found in all organisms, notably the budding yeast $\mathrm{S}$. cerevisiae, and the fruitfly D. 14 melanogaster. Pol $\kappa$ has been shown to bypass a variety of lesions and extend mismatched primers in vitro, although this enzyme does not support TLS across the most frequent types of base damage found in DNA exposed to UV-radiation. Therefore, it is not clear what function Pol $\kappa$ performs in response to UV-radiation (Friedberg et al 2005). On the other hand, specific insight into Pol $\kappa$ function can be gained from studies investigating the relationship between Polא and benzo(a)pyrene, a potent carcinogen found in coal tar and cigarette smoke. The extreme sensitivity of Pol $\kappa-/-$ mouse ES cells to killing and increased mutagenicity is further reinforced with the observation that Pol $\kappa$ is capable of bypassing different stereoisomers of dG-N2-BPDE (the major products generated by benzo(a)pyrene)

efficiently and accurately (Avkin et al 2004). It has also been observed in human cells that BPDE treatment induces the accumulation of GFP-tagged Polк into nuclear foci, and that recovery from BPDEinduced S-phase checkpoint requires Pol к (Bi et al 2005).

\subsubsection{Rev1}

Rev1 is an evolutionarily conserved protein, ubiquitous among eukaryotic species but not represented in prokaryotes. Rev1 is required for UV induced mutagenesis in yeast together with Pol $\zeta$, a B-family polymerase comprised of Rev3 and Rev7 subunits. Rev1 protein possesses deoxycytidyl transferase activity, by which it preferentially inserts dCMP opposite a template base or abasic site, as well as other structurally diverse template lesions in vitro (Jansen et al 2005). In addition, the presence of an N- 
terminal BRCT domain (BRCA1 C-terminal-like) distinguishes Rev1 from the other members of the Yfamily of DNA polymerases. This domain is often found harbored in proteins important for cell-cycle checkpoint functions in response to DNA damage (Jansen et al 2005). In yeast, a single point mutation in the BRCT domain of Rev1 abolishes its ability to bypass abasic sites or [6-4] UV-photoproducts. Indeed, although in yeast Rev1 is required for the bypass of [6-4] UV- photoproducts in vivo, the signature dCMP transferase activity occurs only rarely opposite of a [6-4] photoproduct, suggesting that Rev1 may serve a more indirect role in the bypass of this lesion (Nelson et al 2000; Lawrence and Maher 2001; Gibbs et al 2005). Furthermore, notwithstanding the capacity for Rev1 to bypass abasic sites through its dCMP transferase activity, there is no evidence that the enzymatic activity of Rev1 is required for the replicative bypass of this lesion, further implicating an alternative role for Rev1. Studies aimed to identify non-catalytic functions for Rev1 have been enlightened with discoveries of new Rev1 protein interaction partners. Fruits of this effort have revealed that the C-terminus of mouse and human Rev1 maintains an interaction with several other specialized DNA polymerases, including Pol $\eta$, Pol $\iota$, Pol $\kappa$, and the Rev7 subunit of the B-family polymerase Pol $\zeta$ (Guo et al 2003; Ohashi et al 2004; Tissier et al 2004). The function of these interactions is not known, although it has been demonstrated in yeast that Rev1 enhances the proficiency of the Rev3 subunit of Pol $\zeta$ for the extension of primer termini opposite DNA lesions (Acharya et al 2006). The additional observations that PCNA also interacts with the BRCT domain of Rev1, provided evidence for how Rev1 may function as a key player in the orchestration of DNA translesion synthesis.

\subsubsection{Polymerase Zeta (Pol $\zeta)$}

Pol $\zeta$ is a B-family DNA polymerase, although it maintains properties similar to the Y-family of polymerases, including poor processivity, low fidelity, and the inability to proofread in the 3' -5' direction (Gan et al 2008). In vitro, Pol $\zeta$ primarily functions as an extension DNA polymerase. (Lawrence and Maher 2001). The Pol $\zeta$ protein is comprised of two essential subunits, Rev3 (the catalytic domain) and 
Rev7 (the regulatory domain which enhances the catalytic activity) (Gan et al 2008). Together these subunits function with Rev1 protein in damage-induced mutagenesis among eukaryotes. Pol $\zeta$ 's function in TLS requires the presence of Rev1, although the catalytic activity of Rev1 is entirely dispensable for

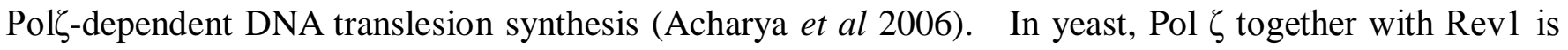
required for the generation of $\sim 98 \%$ of UV-induced base-pair substitutions, as well as the majority of spontaneous mutations (Lawrence 2004). Recent evidence has shown that in yeast, mice, and humans,

the Rev7 subunit of Pol $\zeta$ interacts with Rev1, suggesting that this physical interaction may be evolutionarily conserved for an important function (Guo et al 2003; Acharya et al 2006). In addition, recent evidence has revealed that the C-terminus of yeast Rev1 physically interacts with polymerase domain of Rev3, which enhances the efficiency of Pol $\zeta$ to extend mismatched primer-templates and abasic sites (Acharya et al 2006). Furthermore, the deletion of the Rev1 C-terminal residues which interacts with Rev3 confers the same degree of defective UV-induced mutagenesis and sensitivity to killing as a rev1 $\Delta$ mutation (Acharya et al 2006). Unlike in budding yeast, a deletion of the Rev3 gene in mice results in embryonic death between days 8.5 and 14.5 (Friedberg et al 2005). Nevertheless, these results suggest that there may very well be additional functions for Pol $\zeta$ which have yet to be discovered.

\subsection{PCNA: The sliding clamp}

The appearance of PCNA during the S-phase of the cell cycle implicated its involvement in replication. PCNA was later identified as an essential factor for replication in vitro for the SV40 (simian virus 40) (Prelich et al 1987). The 36kDa PCNA is now understood to be the processivity factor during replication and repair. It tethers the DNA polymerase to the template allowing the synthesis of tens of thousands of base pairs versus approximately ten to fifteen base pairs in its absence, and is essential for chromosomal DNA replication (Ayyagari et al 1995). Functioning as a processivity factor in replication appears to be the main role of PCNA. The sequence of PCNA is well conserved between plants and animals, 
indicating a strong selective pressure for structure conservation, and suggesting that the type of DNA replication mechanism is conserved throughout eukaryotes. Cellular studies have determined that PCNA is present in a pool of about 500,000 monomers/cell (200/1 actin/PCNA ratio and 1/10 RPA/PCNA ratio) (Tanno et al 1996; Bravo et al 1982). This pool is required because PCNA is essential to multiple processes other than DNA replication, such as DNA repair, chromosome remodeling and assembly, chromatid cohesion, and regulating cell cycle checkpoints (Naryzhny et al 2008). The crystal structure of PCNA revealed it to be a closed circular homotrimeric ring with a pseudo-six-fold symmetry. Each monomeric subunit of the PCNA homotrimer consists of two independent domains, with the N-terminal domain referred to as Domain A and the C-terminal domain referred to as Domain B. These independent domains are joined together firmly by forming an extended $\beta$ sheet across the inter domain boundary. Each domain is further connected through a long flexible linker, called the inter domain connector loop (IDCL), that acts as a binding site for various replication associated proteins (Sakurail et al 2005; Bruning et al 2004; Hishiki et al 2009). To form the final ring structure, three monomeric subunits organize in a head-to-tail manner with domain A of one subunit interacting with domain B on an adjacent subunit (Figure 5).

PCNA has a distinct front and back face. The front face of PCNA is involved in proteinprotein interactions and contains the interdomain connecting loop (IDCL) (Zhuang et al 2009; Jonsson et al 1998). The cellular function of PCNA is completely dependent on the protein-protein interactions at the front face of PCNA and there is an ever growing list of PCNA-binding proteins (Maga et al 200; Moldovan et al 2007). This list includes proteins involved in DNA replication, repair, cell cycle control, chromatin remodeling, epigenetic inheritance, chromatid cohesion, and transcription. PCNA interacts with nearly all of these proteins through a hydrophobic groove located on the front side of PCNA at the IDCL. This hydrophobic pocket is composed of a center loop, the C-terminal tail, and the IDCL. It is important to mention that each monomer of PCNA contains an equivalent binding site and this allows for as many as three proteins to bind the PCNA trimer simultaneously. Analysis of PCNA-binding proteins 
has revealed a conserved PCNA-interacting peptide motif (PIP motif) that is defined as $\operatorname{Qxx}(\mathrm{M} / \mathrm{L} / \mathrm{I}) \mathrm{xxF}(\mathrm{Y} / \mathrm{F})$ where $\mathrm{x}$ is any residue. This PIP motif acts as a hydrophobic plug by binding within a hydrophobic pocket on PCNA at the IDCL (Zhuang et al 2009; Naryzhny et al 2008). The PIP motif is often at the C-terminus or in a flexible region of the PCNA-interacting partner. This allows the protein to have a stable tether to PCNA, but does not restrict its movement allowing for some flexibility regarding its orientation with respect to the PCNA ring. Mutations in the conserved PIP motifs of several proteins result in a loss of their function in vivo, highlighting the importance of PIP-PCNA interactions. (Haracska et al 2001a; Gulbis et al 1996; Castrec et al 2009; Ben-Shahar et al 2009; Haracska et al 2001b; Haracska et al 2001c; Vidal et al 2004; Ogi et al 2005). It is thought that the binding of target proteins to PCNA occurs in a competitive manner and is dependent on the local protein concentrations and the affinities of the PIP motifs of the various proteins for

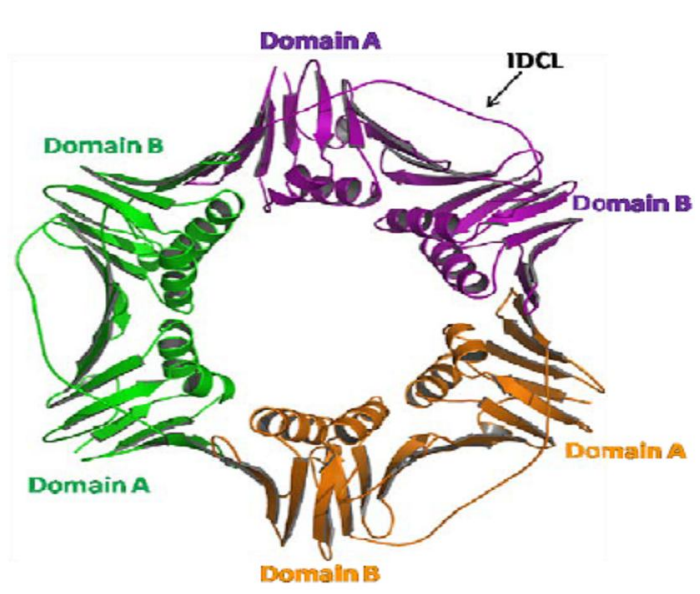
PCNA. It has been shown that the affinity between PIP motifs can be impacted by the flanking sequences and varies by as much as 1000-fold between different PCNA interacting proteins (Castrec et al 2009). At the basic level, PCNA serves as a moving platform sliding along the DNA and interacting with DNA replication proteins (Moldovan et al 2007). This mechanism allows for multiple proteins to interact at the

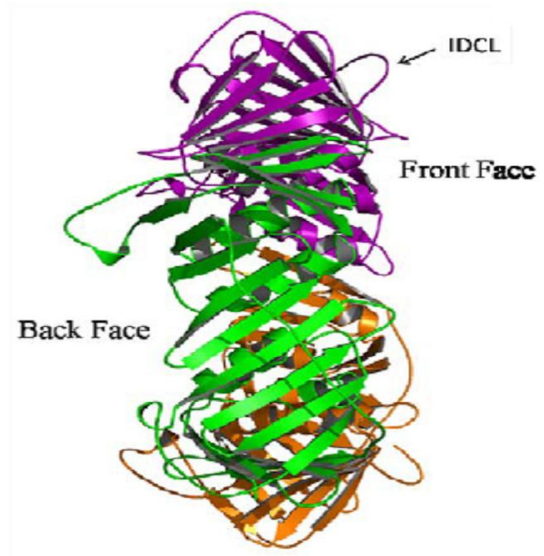
replication fork and remain bound to and slide along the DNA.

Figure 5. X-ray crystal structure of wild type yeast PCNA from the front (upper) and side (lower) view. Each monomeric subunit is shown in purple, green, and orange. Domain A and domain B of each monomeric subunit are indicated. The interdomain connecting loop is indicated for the purple subunit. The front and back faces are indicated in the side view. (PDB ID: 1PLQ) 


\subsubsection{PCNA modifications}

The key regulator of TLS is the replication sliding clamp Proliferative Cell Nuclear Antigen (PCNA). The PCNA trimer holds multiple proteins that participate in both normal replication and TLS. The role of PCNA in TLS is governed by post-translational modifications that occur to it in response to an arrested fork. With so many processes utilizing PCNA, the cell has developed additional methods of regulation through modifications of PCNA. These include sumoylation, monoubiquitylation, and polyubiquitylation (Lehmann et al 2007; Ulrich 2005; Lee and Myung 2008; Moldovan et al 2007; Ulrich 2007a; Ulrich 2007b).

PCNA is monoubiquitylated at a highly conserved lysine residue, K164, by the Rad6/Rad18 complex. Ubc13/Mms2 in cooperation with Rad5 can then extend this modification to a polyubiquitin chain of an unconventional, non-proteolytic K63 linkage (Hofmann et al 1999; Hoege et al 2002). Both modifications are induced by DNA damage or replication stress and promote the two branches of damage bypass (Figure 6). Based on genetic evidence, polyubiquitylation of PCNA is a requirement for the errorfree pathway (Hoege et al 2002); PCNA monoubiquitylation at K164 has been demonstrated in many organisms now, ranging from budding and fission yeast to human and chicken DT40 cells as well as Xenopus laevis egg extracts ( Hoege et al 2002; Kannouche et al 2004; Watanabe et al 2004; Arakava et al 2006; Frampton et al 2006; Leach and Michael 2005; Simpson et al 2006). K63-linked polyubiquitin chains on PCNA are clearly detectable in budding and fission yeast as well as X. laevis egg extracts, human cells (Hoege et al 2002; Stelter et al 2003; Leach and Michael 2005; Motegi et al 2008; Motegi et al 2006; Unk et al 2008; Unk et al 2006)

The SUMOylation of PCNA and its functions are known mainly from the studies coming from Saccharomyces cerevisae. One function of the sumoylation at Lys-164 is to recruit the Srs2 helicase-like enzyme that will strip the recombinase Rad51 off the DNA (Papouli et al 2005). This helps to prevent any unwanted homologous recombination during $\mathrm{S}$ phase (Figure 6). The second 
function of Lys-164 sumoylation has been postulated to act as a switch between DNA replication and DNA damage tolerance. When the cell is in S phase there is an increase in the sumoylation of PCNA and it is believed that upon DNA damage there is a switch from sumoylation to ubiquitylation, promoting the DNA damage tolerance pathway (Hoege et al 2002; Parker et al 2008; Stelter et al 2003). Although PCNA SUMOylation has been reported in higher eukaryotes such as in Xenopus and chicken cells, the SUMO dependent regulation of recombination has been assumed to be important only in particular eukaryotic cells with a naturally high rate of recombination such as yeast ( Hoege et al 2002; Leach and Michael 2005). Only recently in a parallel study, SUMOylation of human PCNA has also been found and shown that it preferentially interacts with a PCNA interacting protein (PARI). PARI was suggested to suppress inappropriate recombination events at the replication fork; however, the direct role of SUMO modification of human PCNA has not been studied (Moldovan et al 2012).

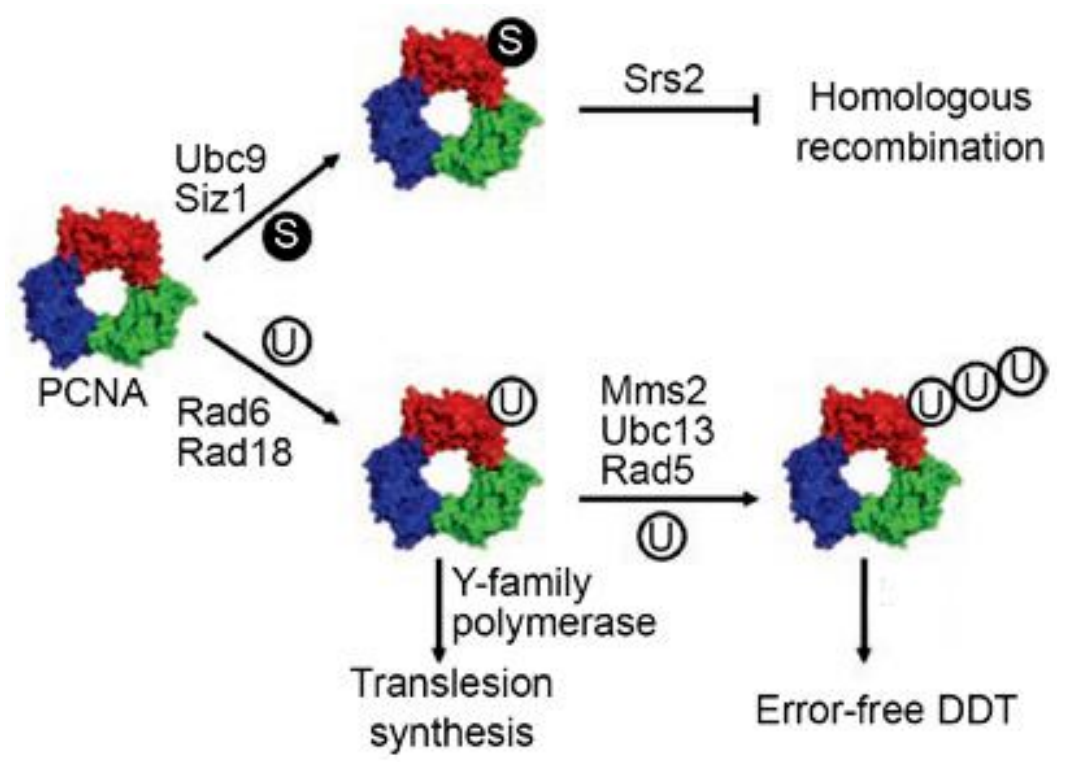

Figure 6. A model established in S.cerevisiae for the role of PCNA covalent modifications in DNA damage tolerance pathways. 


\section{Main objectives of the Thesis}

Important objective of this thesis was to better understand the role of DNA damage tolerance mechanisms in maintaining genome stability and preventing cancer-prone human disorders. Specifically

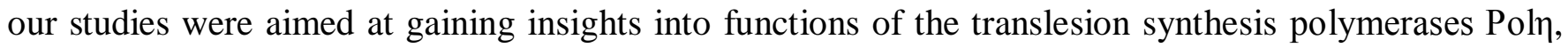
Rev1 and Rev3; establishing SUMO-PCNA dependent mechanisms in human cells. Towards the above mentioned aims we addressed the following questions:

- PCNA is known to play a critical role in polymerase exchange process at the site of a DNA lesion, so we asked what is the role of UBZ and PIP domains of Polymerase $\eta$ in gaining access to the replication foci with PCNA?

- Translesion synthesis polymerases are proposed to play a central role in the bypass of damaged DNA template, therefore we asked if Rev1 and Rev3 deficiency in cells effect the progression of replication of UV damaged DNA?

- Inappropriate recombination can have deleterious effects on the genome. SUMO-PCNA in yeast is known to regulate recombination. It is not known in detail how human cells deal with collapsed replication forks and inappropriate recombination events? Are SUMO-PCNA dependent mechanisms conserved in human cells? 


\section{Experimental Methods}

\subsection{Generation of hPol $\eta$ Mutations}

WT and mutant hPol $\eta$ plasmid constructs, generation of mutations and cloning strategy was previously described (Haracksa et al 2001b). Briefly, site-directed mutagenesis was performed on WT hPol $\eta$ to generate mutations in the PIP1 domain (F443A, L444A) and PIP2 domain (F707A, F708A), yielding PIP1, PIP2 and double mutant (F443A, L444A, F707A, F708A) hPol $\eta$. UBZ site-specific mutations (C635A, H650A, D652A, H654A, and F655A) in the UBZ domain were generated in WT hPol $\eta$.

\subsection{Cell culture, transfections and stable cell lines}

MRC5, HeLa, SW480 SN3 and HEK293 cells were cultured in DMEM supplemented with 10\% FCS and antibiotics. Cells were transfected with Lipofectamine 2000 (Invitrogen) according to the manufacturer's instruction. For generation of cell lines stably expressing FLAG-PCNA or FLAG-PCNA-SUMO1 conjugate in HeLa cells, cells were selected after $24 \mathrm{~h}$ of transfection in medium containing $1 \mu \mathrm{g} / \mathrm{ml}$ puromycin or $300 \mu \mathrm{g} / \mathrm{ml}$ Hygromycin B, respectively, before single colonies were isolated and tested for stable protein expression.

\section{3 hPol $\eta$ localization- Immunocytochemistry and Fluorescence Microscopy}

WT and mutant hPol $\eta$ genes, cloned into p3X Flag CMV7.1 vector (Sigma) were provided by Satya Prakash laboratory at the University of Texas medical branch and the construct, GFP-PCNAL2, for expressing GFP-PCNA was a kind gift from M. Cristina Cardoso at the Max Delbrck centre for molecular medicine, Germany. SV40-transformed MRC5 HF (AG10076) cells grown on coverslips were transfected with different plasmid constructs, and $24 \mathrm{~h}$ after transfection, cells were UV-irradiated at 40

$\mathrm{J} / \mathrm{m}^{2}$ followed by incubation for $6 \mathrm{~h}$. Cells were then rinsed in PBS and fixed in cold methanol for 10 
min. Cells were subsequently washed twice with PBS and blocked with PBS $+1 \%$ BSA for 20 min followed by incubation with primary antibody diluted in $1 \%$ BSA containing PBS for $1 \mathrm{~h}$. Cover slips were washed 5 times with PBS and incubated with Cy3-conjugated anti-mouse antibody again diluted in PBS containing $1 \%$ BSA. After washing 5 times with PBS, cover slips were mounted with mounting media containing glycerol and DAPI. Stained cells were analyzed and photographed with an Olympus confocal laser scanning microscope. Antibodies used were mouse anti-FLAG mAb 1:400, M2 (Sigma F3165) and anti-mouse Cy3 1:1,000 (Sigma C2181).

\subsection{Isolation, immortalization, and culturing of $\operatorname{Rev1}^{\mathrm{B} / \mathrm{B}}, \operatorname{Rev1}^{-/-}$and $\operatorname{Rev}^{-/-} \mathrm{MEFs}^{-\mathrm{S}}$}

Mouse embryonic fibroblasts deficient for the expression of Rev1 BRCT domain, Rev1 or Rev3 were provided by Niels de Wind (Leiden University Medical Center, Netherlands). Briefly, Wild-type, $\operatorname{Rev}^{\mathrm{B} / \mathrm{B}}$, $\operatorname{Rev1}^{-/-}$and Rev3 ${ }^{-/-}$MEFs of hybrid 129/Ola and C57BL/6 background were isolated from embryos of crosses of $\mathrm{Rev}^{\mathrm{B} /-}$, $\mathrm{Rev}^{+/-}$or $\mathrm{Rev}^{+/-}$mice. Mouse embryonic fibroblasts (MEFs) were isolated by trypsinization of finely minced, 13.5 -day-old embryos at $37^{\circ} \mathrm{C}$ for $15 \mathrm{~min}$. MEFs were cultured in MEF medium (Dulbecco's modified Eagle's medium containing 4,500 mg/liter glucose, GlutaMax, and pyruvate [Invitrogen]) supplemented with $10 \%$ heat-inactivated fetal calf serum, antibiotics, and $0.4 \mu \mathrm{M}$ 2-mercaptoethanol (Invitrogen) at $37^{\circ} \mathrm{C}$ and $5 \% \mathrm{CO} 2$.

\subsection{Labeling of replicating DNA and generation and visualization of DNA fibers}

Exponentially growing MEFs were pulse labeled with $25 \mu \mathrm{M}$ iododeoxyuridine (IdU) at $37^{\circ} \mathrm{C}$ for 20 min, mock treated or exposed to either $20 \mathrm{~J} / \mathrm{m} 2$ or $40 \mathrm{~J} / \mathrm{m} 2 \mathrm{UV}-\mathrm{C}$ light, and labeled with $250 \mu \mathrm{M}$ bromodeoxyuridine (BrdU) for 20, 40, or $60 \mathrm{~min}$. Isolation of DNA fibers and immunolabeling were carried out as described previously (25). Briefly, $2 \mu \mathrm{l}$ of cells resuspended in PBS (10 ${ }^{6}$ cells $\left./ \mathrm{ml}\right)$ was diluted 1:1 with unlabeled cells and spotted onto cleaned glass slides. Cells were lysed with $7 \mu 1$ of $0.5 \%$ sodium dodecyl sulfate (SDS) in $200 \mathrm{mM}$ Tris- $\mathrm{HCl}$ (pH 5.5)-50 mM EDTA (6 min at 20 $\mathrm{C}$ ). Slides were tilted at $15^{\circ}$ to horizontal, allowing a stream of DNA to run slowly down the slide. Next, slides were air 
dried and then fixed in methanol-acetic acid (3:1). Fixed DNA fiber spreads were hydrated and denatured (2.5 $\mathrm{M} \mathrm{HCl}$ for $1 \mathrm{~h})$. BrdU incorporation was detected using anti-BrdU (1:1,000; Ab-Direct Serotech) and AlexaFluor 488-labeled goat anti-rat antibody (1:1,000; Molecular Probes, Inc.) antibodies. Mouse antiIdU/BrdU (1:1,000; Caltag Laboratories) and Cy3-labeled sheep anti-mouse antibody (1:1,000; Sigma Aldrich) were used to detect IdU incorporation. Finally, slides were thoroughly rinsed and mounted in mounting medium containing glycerol and 4, 6-diamidino-2 phenylindole (DAPI). Spread and immunolabeled DNA fibers were imaged using an Olympus confocal laser scanning microscope. The lengths of DNA tracts corresponding to IdU and BrdU labeling were measured using Olympus software, and IdU/BrdU ratios were analyzed.

\subsection{Generation of expression constructs for PCNA SUMOylation}

For expression in human cells, the cDNAs of human SUMO1, SUMO2, and SUMO3 were cloned into BamHI and XmnI sites of pENTR2B (Invitrogen) and subsequently in fusion with FLAG-tag in pRK2F mammalian expression vector (Gateway cloning; Invitrogen); the cDNA of human UBC9 was cloned into EcoRI and XhoI sites of pENTR3C (Invitrogen) and subsequently in fusion with His-tag in pDest26 vector (Gateway cloning; Invitrogen) ; the cDNA of wild-type human PCNA and lysine to arginine point mutant PCNAs that were generated by PCR-based method were cloned into BamHI and XmnI sites of pENTR1A (Invitrogen) and subsequently in fusion with HA-tag in pRK2H vector (Gateway cloning; Invitrogen); primers used for the generation of PCNA mutants are listed in the supplementary information as Table 1 in page.64, briefly after the mutagenic PCR, amplified products are digested with DpnI at $37^{0} \mathrm{C}$ for $1 \mathrm{hr}$ before transformation; the stop codon at the C-terminal of PCNA was removed by site-directed mutagenesis. PCNA-SUMO1 fusion was generated by PCR, and the sequence-verified PCR product was cloned in fusion with FLAG-tag in pRK2F vector into BamHI and HindIII sites. For protein purification PCNA point mutants were cloned in fusion with GST in a pBJ842 yeast expression vector; the cDNAs of PIAS1, PIAS2, PIAS3, and PIAS4 were cloned into EcoRI and XhoI sites of pENTR3C 
(Invitrogen) and subsequently in fusion with GST-tag in pGEX-6 vector (Gateway cloning; Invitrogen).

\subsection{Proteins}

Wild type and mutant GST-PCNAs were expressed in BJ5464 yeast strain. Cells were grown in synthetic medium lacking leucine to select for the plasmids. The cultures were diluted 10-fold in fresh medium lacking dextrose but containing 2\% lactic-acid and 3\% glycerol followed by incubation overnight before galactose was added to $0.2 \%$ final concentration. Seven hours after induction cells were harvested and disrupted by bead beater. SUMO1, SUMO2, SUMO3, UBC9, SAE1/2, PCNA-SUMO1, Pias1, Pias2, Pias3, and Pias4 proteins were expressed in BL21 (DE3) Codon Plus-RIL bacterial strain. Cells were grown into logarithmic phase at $16^{\circ} \mathrm{C}$ in $\mathrm{LB}$ media containing $100 \mu \mathrm{g} / \mathrm{ml}$ ampicillin and IPTG was added to $0.1 \mathrm{mM}$ final concentration. Three hours after induction cells were harvested and disrupted by sonication. For their purification, total cell protein extracts were prepared in buffer A (20 mM Tris- $\mathrm{HCl}$ ( $\mathrm{pH} 7.5$ ), $0.01 \%$ Nonidet P-40, $10 \%$ glycerol) followed by supplementing the lysate with $1 \mathrm{M} \mathrm{NaCl}, 5$ mM EDTA, and protease inhibitors (Mini-Complete, Roche) before centrifugation and loading the supernatant onto a glutathione-Sepharose column (Amersham Pharmacia Biotech). Unbound proteins were washed away with buffer A+1 M NaCl followed by buffer A+100 mM NaCl. Finally, GST-fusion proteins were eluted from glutathione-sepharose in buffer A+100 mM NaCl containing $10 \mathrm{mM}$ glutathione, or proteins without GST-fusion were eluted with PreScission protease.

\subsection{Flow cytometric analysis}

Exponentially growing stable cell lines expressing FLAG-control, FLAG-PCNA or FLAG-PCNASUMO1 were harvested, washed with PBS and fixed in $70 \%$ ethanol. Cells were RNaseA $(0.2 \mu \mathrm{g} / \mathrm{ml})$ treated for $15 \mathrm{~min}$ at $37^{0} \mathrm{C}$ and stained with propidium iodide $(50 \mu \mathrm{g} / \mathrm{ml})$. Flow cytometric profiles were determined using a Becton-Dickinson FACScan and analysed with ModFitLT software.

\subsection{Cell lysis and immunoprecipitations}

Cells were lysed in a buffer containing $50 \mathrm{mM}$ Tris- $\mathrm{HCl}$ (pH7.5), $400 \mathrm{mM} \mathrm{NaCl,} 1 \%$ NP-40, $0.1 \%$ SDS, 
$5 \mathrm{mM}$ EDTA, $10 \%$ glycerol and $1 \mathrm{mM}$ PMSF. Cell lysates were briefly sonicated and clarified by centrifugation at $25,000 \mathrm{~g}$ for $10 \mathrm{~min}$ at $4^{\circ} \mathrm{C}$. Supernatants were diluted with equal volume of dilution buffer (lysis buffer without $\mathrm{NaCl}$ ) and FLAG-tagged proteins were immunoprecipitated using anti-FLAG M2 affinity gel (Sigma). FLAG precipitates and initial cell lysates were analyzed by western blot using anti-FLAG M2 (Sigma F3165), anti-HA 3F10 (Roche) and anti-PCNA PC-10 (Santa Cruz) antibodies.

\subsection{Recombination assay}

SW480 SN3 cells containing SCNeo recombination substrate is an established recombination reporter system that has been previously described (Mohindra et al 2002). Briefly, reporter cells were cotransfected with a control empty vector, PCNA, SUMO1 or PCNA-SUMO1 fusion protein expressing vectors, and also with pCMV3nls-I-SceI expression vector that introduces a DNA DSB, using Lipofectamine 2000 (Invitrogen). Recombination frequencies were determined after selection in media containing $1 \mathrm{mg} / \mathrm{ml} \mathrm{G} 418$ for 2 weeks and staining with $0.4 \%$ methylene blue/50\% methanol. 


\section{Results and Conclusions}

\subsection{Roles of PCNA-binding and ubiquitin-binding domains in human DNA polymerase $\eta$ in translesion DNA synthesis}

It has been postulated that the Ubiquitin Binding Domain-mediated binding of TLS Pols to the Ubiquitin moiety on PCNA is necessary for translesion synthesis (Bienko M, et al 2005; Guo et al 2006; Plosky et al 2006). To test the validity of this model, we examined the contributions that the PIP and Ub-binding zinc finger (UBZ) domains of human Poln make to its functional interaction with PCNA, for this we analyzed the co-localization of hPol $\eta$ with PCNA in replication foci.

\subsubsection{Identification of an additional PCNA-binding PIP motif in hPol $\eta$.}

Mutational inactivation of the hPol $\eta$ PIP domain does not confer the same high degree of defectiveness in its ability to interact with PCNA and perform TLS in human cells (Haracska et al 2001b). The observation that residual PCNA-binding ability is still retained in the hPol $\eta$ PIP mutant protein raised the possibility that $\mathrm{hPol} \eta$ harbors an additional PIP domain that can promote PCNA binding. In support of such a possibility, we noted the presence of an additional PIP-like motif in hPoln that lies between residues 437 and 444, just C-terminal to the polymerase-associated domain (PAD) region.. We have named this motif PIP1 and the C-terminal motif that lies between residues 701-708 PIP2 (Figure 7).

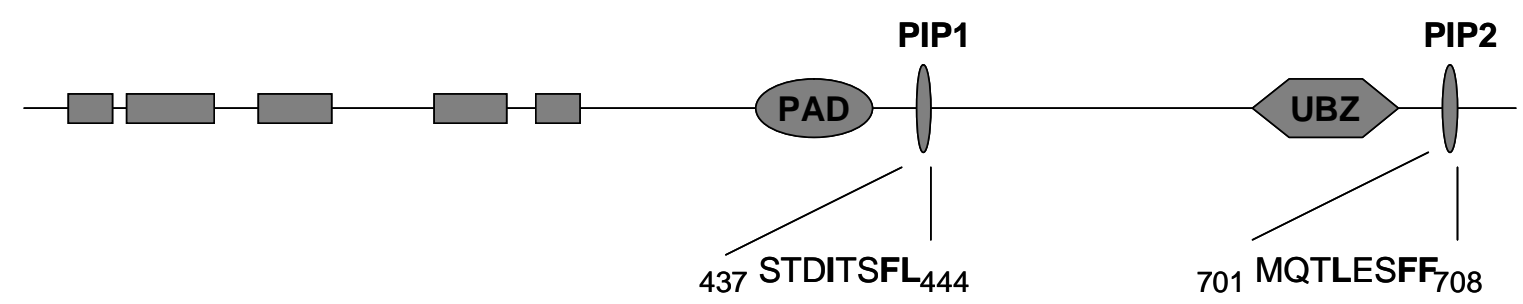

Figure 7. Schematic representation of the PIP domains of human Polymerase $\eta$ and the highly conserved hydrophobic residues of the PIP domain are shown in bold. 


\subsubsection{Requirement of PCNA-binding PIP domains for accumulation of hPol $\eta$ in}

\section{replication Foci.}

$\mathrm{hPol} \eta$ colocalizes with PCNA in replication foci, and the level of hPol $\eta$ accumulation in foci is greatly increased in UV-irradiated human cells (Kannouche $\mathrm{P}$ et al 2001). To evaluate the contribution of the PIP1 and PIP2 domains to the accumulation of hPol $\eta$ in foci, we cotransfected MRC5 fibroblasts with WT GFP PCNA and with WT or PIP1 and/or PIP2 FLAG - Pol $\eta$. WT Pol $\eta$ (stained red) and PCNA (stained green) both accumulate in foci in UV-irradiated human cells, and a great majority of hPol $\eta$ foci colocalize with PCNA as indicated from the appearance of yellow foci. Interestingly, hPol $\eta$ foci formation or its colocalization with PCNA are not affected by the F443A, L444A PIP1 or the F707A,F708A PIP2 mutations. Importantly, hPol $\eta$ protein bearing mutations in both the PIP1 and PIP2 domains did not accumulate in replication foci, and there was no evidence for the colocalization of this mutant hPol $\eta$ with PCNA as indicated from the absence of any yellow foci (Figure 8). We conclude that these observations that the coincident accumulation of hPol $\eta$ with PCNA in replication foci requires that the ability to bind PCNA via one of its PIP domains be retained.

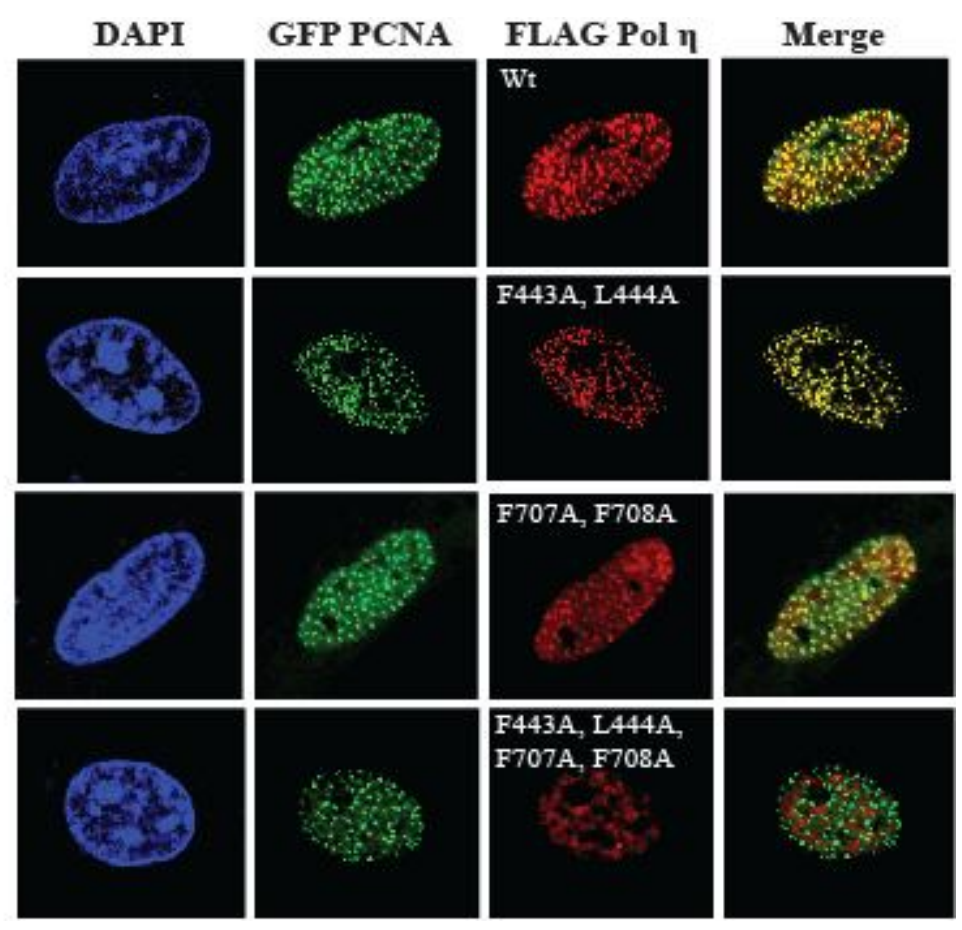

Figure 8. PCNA binding by PIP domains is essential for accumulation of hPol $\eta$ in replication foci. MRC5 cells were cotransfected with WT GFP PCNA and WT FLAG Pol $\eta$ or PIP1 (F443A, L444A), PIP2 (F707A, F708A), or PIP1, PIP2 (F443A, L444A, F707A, F708A) mutant FLAG Poln. Twenty-four hours after transfection, cells were UV-irradiated with $40 \mathrm{~J} / \mathrm{m}^{2}$ followed by incubation for $6 \mathrm{~h}$ before fixation. FLAG-tagged hPol $\eta$ proteins were imunostained with anti-FLAG mAb. (Magnification: 600x.) 


\subsubsection{Accumulation of hPol $\eta$ UBZ mutant proteins in replication Foci.}

The inactivation of PCNA binding by the PIP1, PIP2 mutation results in complete loss in hPol $\eta$ 's ability to accumulate in replication foci with PCNA. We further examined the effects of different UBZ mutations, on accumulation of $\mathrm{hPol} \eta$ in replication foci in UV-irradiated human cells. We found that the abilities to accumulate in replication foci and colocalize with PCNA are retained by the various UBZ mutations that we studied. Our observations that C635A, H650A, and H654A mutations in the C2H2 zinc finger do not affect foci formation in UV-irradiated human cells, imply that the mutational inactivation of zinc finger of the UBZ domain and the consequent inactivation of its ability to bind ubiquitin have no significant impact on ability of hPol $\eta$ to accumulate in foci and colocalize with PCNA. Our analyses with the D652A and F655A mutations, which also inactivate Ubiquitin-binding ability of hPol $\eta$ but not colocalization with PCNA, add further support to our conclusion that foci formation and colocalization with PCNA can still occur in hPol $\eta$ UBZ mutant proteins that have lost ability to bind Ub (Figure 9).

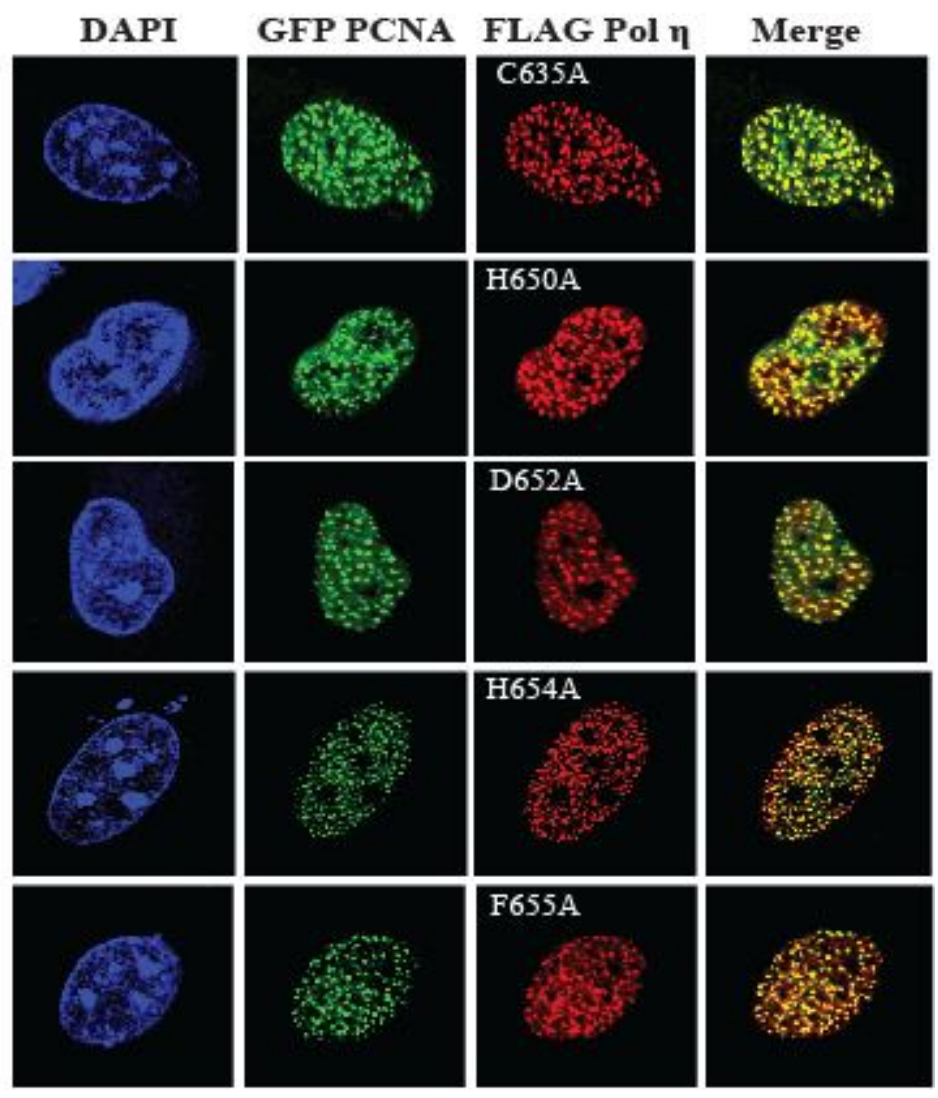

Figure 9. UBZ mutant hPol $\eta$ proteins accumulate in replication foci. MRC5 cells were cotransfected with WT GFP PCNA and UBZ mutant FLAG Pol $\eta$ as indicated. Twenty-four hours after transfection, cells were UV-irradiated with $40 \mathrm{~J} / \mathrm{m}^{2}$ followed by incubation for 6 $\mathrm{h}$ before fixation. FLAG-tagged proteins were immunostained with anti-FLAG mAb. (Magnification: 600x.) 


\subsection{Regulatory roles of Rev1 in DNA damage bypass}

To elucidate the mechanism by which Rev1 promotes DNA damage bypass, we have analyzed the progression of replication on UV light-damaged DNA in mouse embryonic fibroblasts that contain a defined deletion in the N-terminal BRCT domain of Rev1 or that are deficient for Rev1 by DNA fiber labeling, a sensitive assay to determine the progression of replicons on single DNA molecules in vivo. Two periods of DNA synthesis are marked by the incorporation of different halogenated nucleotides, IdU and BrdU. DNA that has incorporated these bases can be visualized by fluorescence microscopy of combed DNA fibers stained with specific antibodies (Figure 10). This enables to monitor rate of replication fork progression during first labeling, and fork stalling during the second labeling period. 1 $\mu \mathrm{m}$ of DNA represents $2.59 \pm 0.24 \mathrm{~kb}$ (Jackson and Pombo, 1998). Using this figure, we estimate an average fork progression rate of $1 \mathrm{~kb}$ per minute.

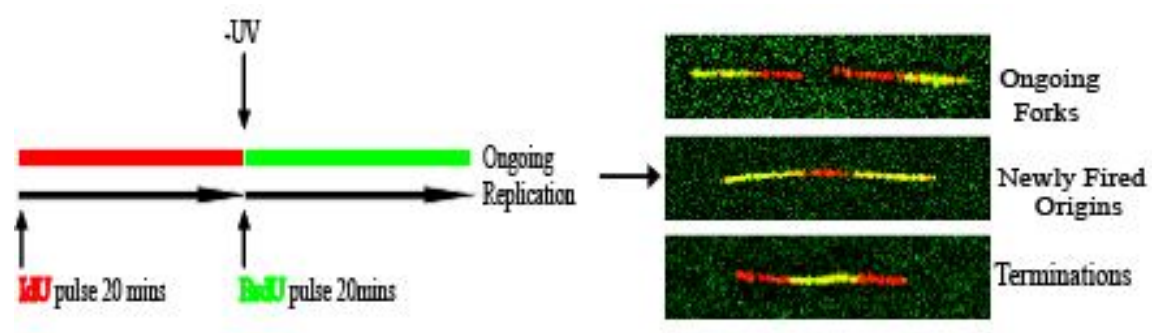

Replacting Fods

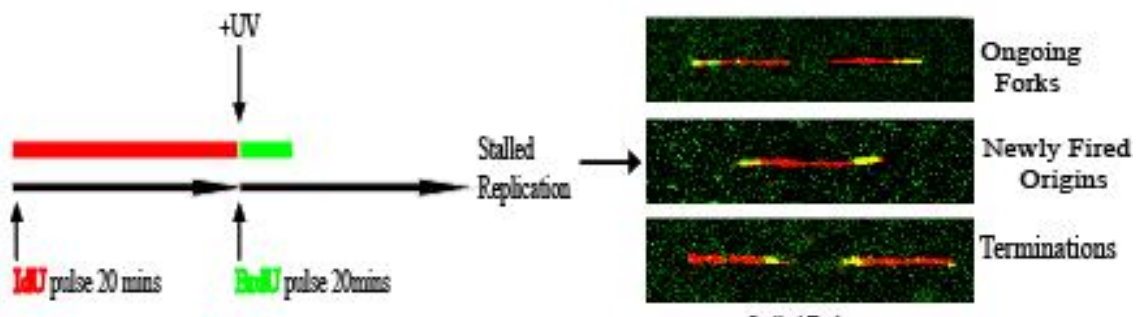

Salled Fouks

Figure 10. Schematic representation of replication labeling and representative replication forks during ongoing and stalled replication. 


\subsubsection{The Rev1 BRCT domain is essential for an early pathway for bypassing UV-}

damaged DNA.

$\operatorname{Rev1}{ }^{\mathrm{B} / \mathrm{B}}$, and $\mathrm{Rev1}^{-{ }_{-}} \mathrm{MEF}$ cells were incubated with IdU for $20 \mathrm{~min}$ to label replicating DNA, exposed to 0 to $40 \mathrm{~J} / \mathrm{m} 2 \mathrm{UV}-\mathrm{C}$, and subsequently incubated with BrdU for 20 to $60 \mathrm{~min}$. Combed DNA was stained by specific antibodies for IdU and BrdU and visualized by fluorescent microscopy, and finally tract lengths and replication rates during IdU and BrdU labeling were determined (Figure 10, 11). Under normal replication conditions, at an undamaged template, the ratio of IdU to BrdU is expected to be approximately 1. Mock-treated wild-type, $\operatorname{Rev} 1^{\mathrm{B} / \mathrm{B}}$, and $\mathrm{Rev1}{ }^{-1-}$ MEFs indeed showed a ratio of approximately 1 and displayed similar replication rates (Figure 11).

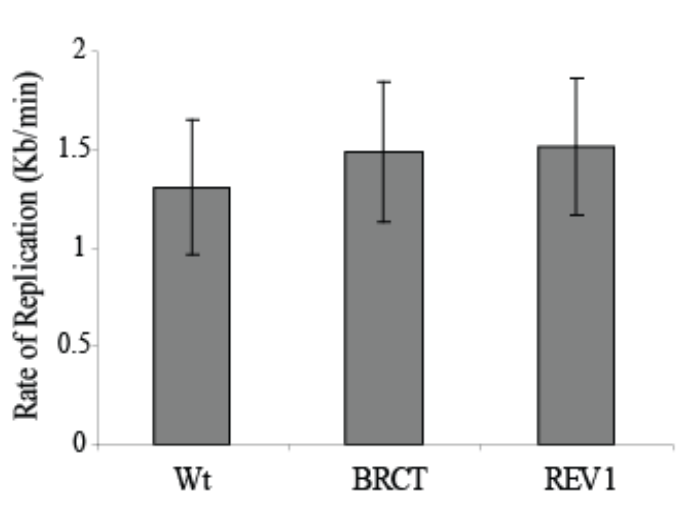

Figure 11. Replication fork progression in undamaged wild type and Rev1-mutant MEF lines. Replication rates were determined by measuring IdU tract lengths assuming $1 \mu \mathrm{M}$ of DNA $=2.59 \pm 0.24 \mathrm{~kb}$

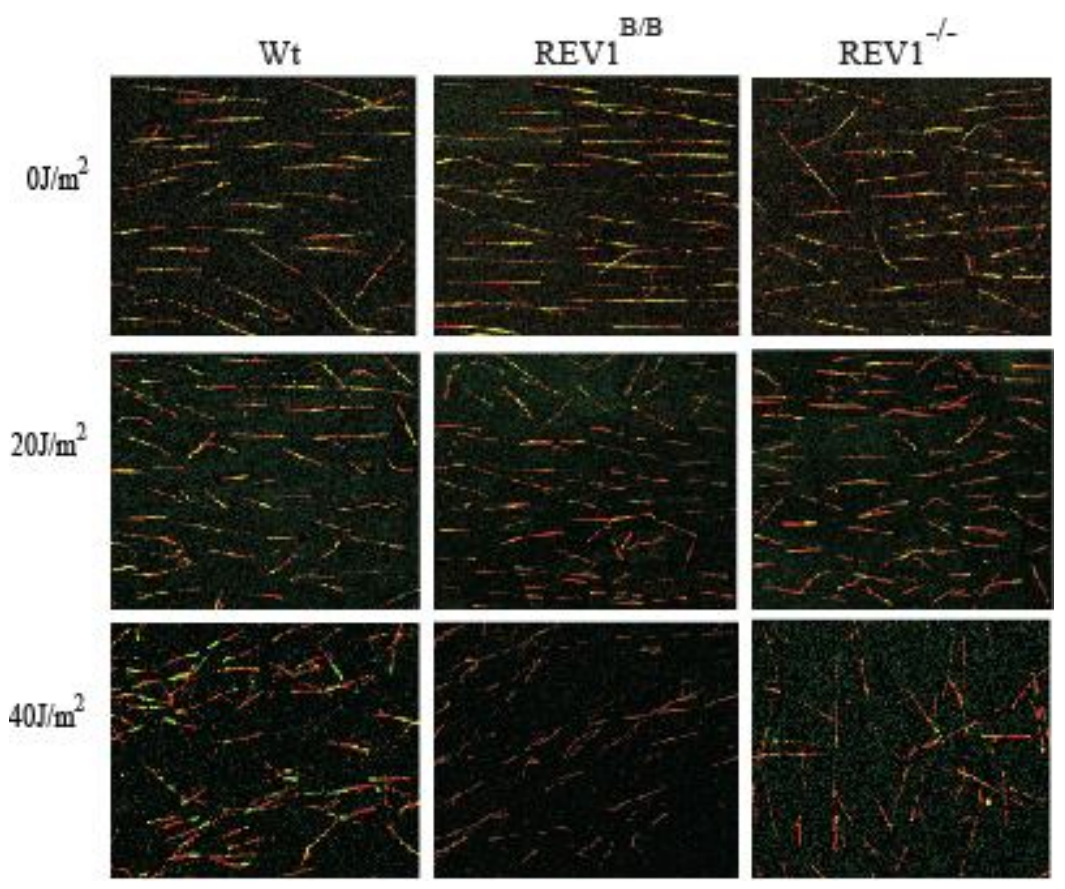

Figure 12. Representative set of DNA fibers of wildtype (Wt), Rev $1^{\mathrm{B} / \mathrm{B}}$, and $\mathrm{Rev} 1^{-/-}$MEFs exposed to 0 , 20 , or $40 \mathrm{~J} / \mathrm{m}^{2} \mathrm{UV}-\mathrm{C}$.

This indicates that Rev1 is dispensable for replication fork progression on undamaged DNA. Following exposure to $20 \mathrm{~J} / \mathrm{m}^{2}$ or $40 \mathrm{~J} / \mathrm{m}^{2} \mathrm{UV}-\mathrm{C}$, however, Rev1 ${ }^{\mathrm{B} / \mathrm{B}}$ and Rev1 $1^{-/-}$MEFs showed much stronger, and 
very similar, increases in the ratio of IdU to BrdU than wild-type MEFs (Supplementary Figure 1, Figure 13). This suggests a defect in an early DNA damage bypass mode in both Rev1mutant cell lines. A time course experiment revealed that, following the UV-C exposure, average tract lengths of nascent DNA fibers in $\operatorname{Rev} 1^{\mathrm{B} / \mathrm{B}}$ and Rev1 $1^{-/-}$MEFs slightly increased in time although to a much smaller extent than in wild-type MEFs (Figure 14). Stable expression of a mouse Rev1 cDNA in Rev1 ${ }^{\mathrm{B} / \mathrm{B}}$ and $\operatorname{Rev1}^{-/-} \mathrm{MEFs}^{-}$ corrected the defect in fork progression, demonstrating that the phenotype is attributable to the Rev1 mutations (Supplementary Figure 1, Figure 13). Since $\operatorname{Rev1}^{\mathrm{B} / \mathrm{B}}$ and Rev1 ${ }^{-/}$MEFs display similar phenotypes, we conclude that early progression of forks stalled at UV damage requires a functional Rev1 BRCT domain.
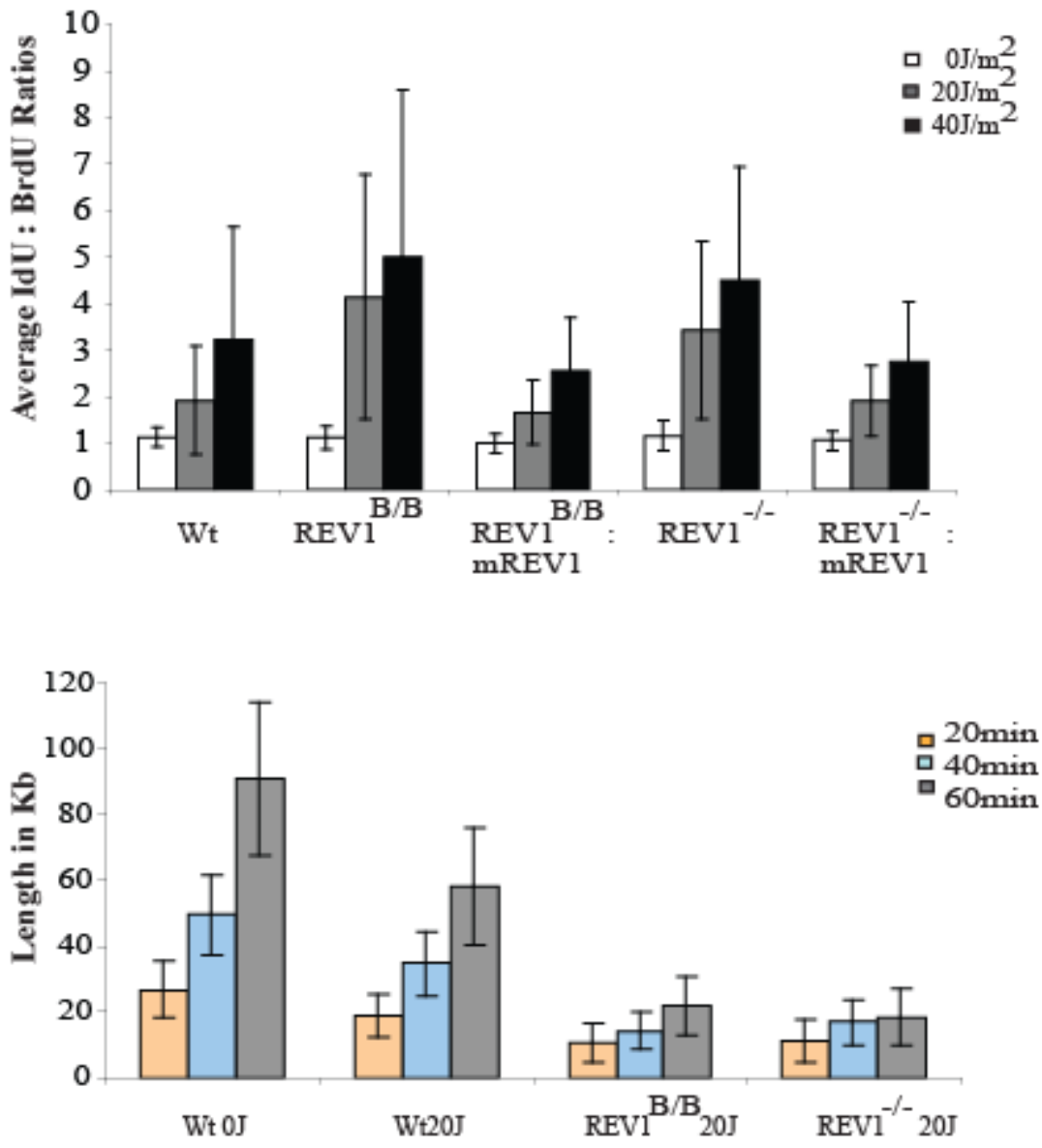

Figure 13. Average ratio of IdU to BrdU in wild-type, $\operatorname{Rev1} 1^{\mathrm{B} / \mathrm{B}}$, and Rev1 ${ }^{-/-}$MEFs and Rev1 mutant MEFs complemented with mouse Rev1.
Figure 14. Length of replicating forks during BrdU labeling in unexposed wild-type cells and wildtype, $\operatorname{Rev} 1^{\mathrm{B} / \mathrm{B}}$, and $\mathrm{Rev1}^{-/-}$ MEFs at 20, 40, and $60 \mathrm{~min}$ after exposure to $20 \mathrm{~J} / \mathrm{m} 2$ UV-C. 


\subsection{Role of Polymerase Zeta in the bypass of UV induced DNA lesions.}

DNA polymerase $\zeta(\operatorname{Pol} \zeta)$, composed of the catalytic Rev3 and accessory Rev7 subunits is an important player in replication of damaged DNA templates (Masuda et al 2003; Guo et al 2003; Murakumo et al 2001; Acharya et al 2006) and, together with the Y family DNA polymerase Rev1, is responsible for most DNA damage-induced mutagenesis in eukaryotic cells (Gan et al 2008). To better define the role of polymerase $\zeta$ in DNA damage tolerance in mammalian cells, we have investigated replication of ultraviolet light-damaged DNA templates in mouse embryonic fibroblasts deficient for Rev3 by DNA fiber labeling (Figure 15, 16).

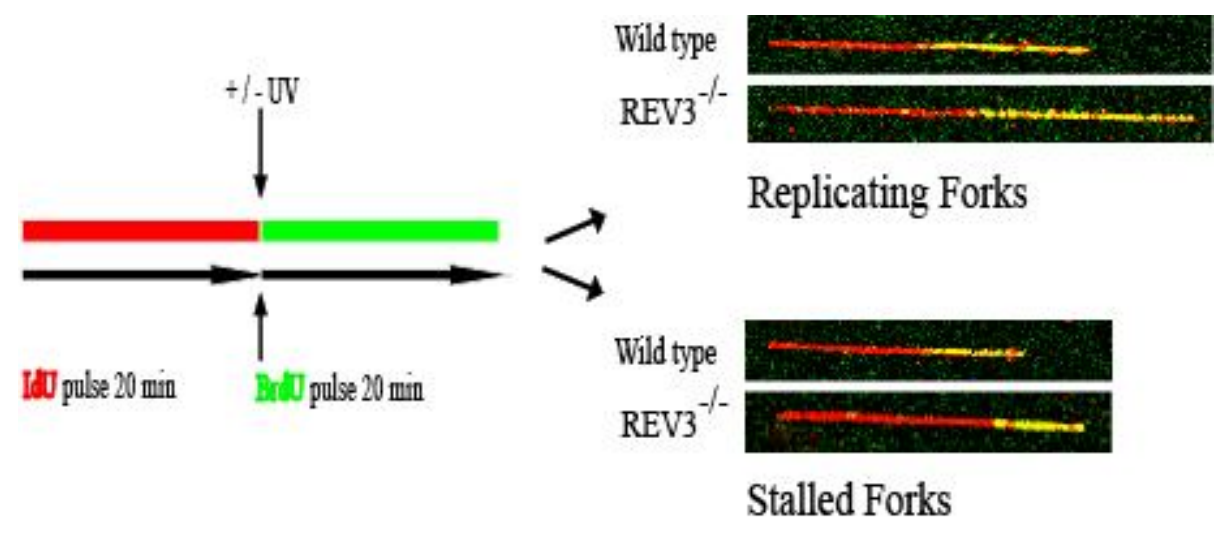

Figure 15. Schematic representation of replication labeling and representative replication forks during ongoing and stalled replication.
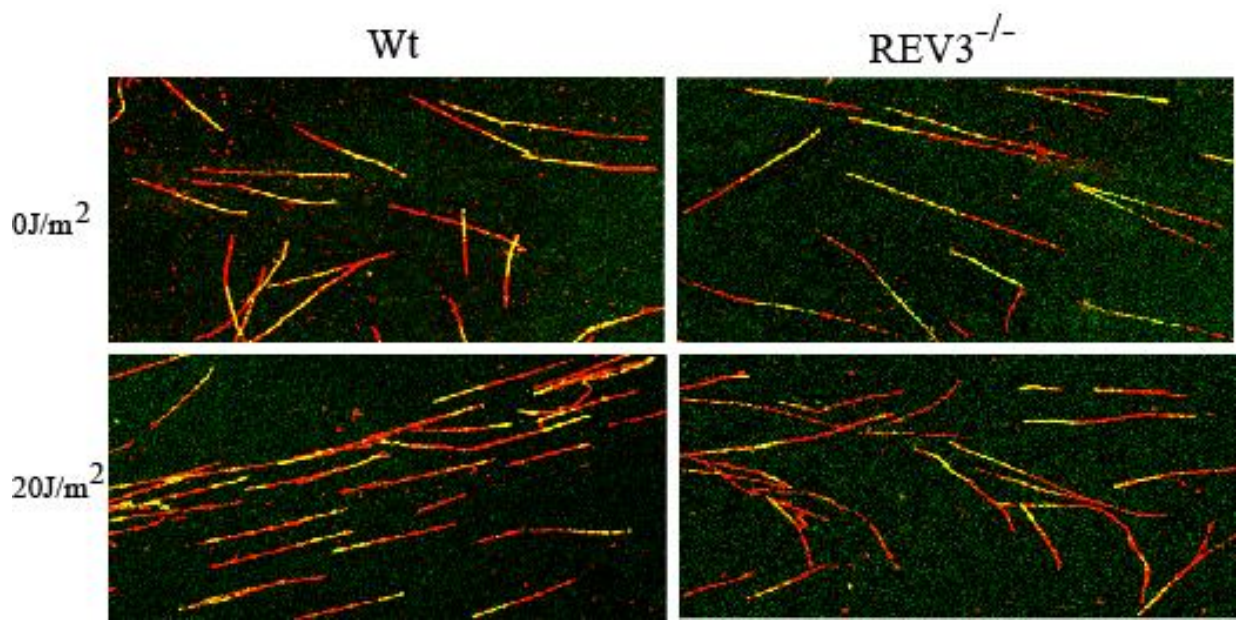

Figure 16. Representative set of DNA fibers from wild type and Rev $3^{-/-}$MEFs exposed to 0 or $20 \mathrm{~J} / \mathrm{m}^{2} \mathrm{UV}-\mathrm{C}$. 


\subsubsection{Mammalian Rev3 is not essential for early translesion synthesis.}

Prior to UV-C treatment, nascent DNA was pulse labeled with IdU. Following UV-C treatment, cells were labeled for different time periods with BrdU. DNA fiber spreads were prepared and stained with fluorescent antibodies against each of the halogenated nucleotides. The ratio of red (representative of IdU) and green (representative of BrdU) fluorescence is a measure of the extension of replication forks. On undamaged DNA, fork progression was quite similar, i.e. about 1.3 and $1.75 \mathrm{kbp} / \mathrm{min}$ for wild type and Rev3-8 cell lines, respectively (Figure 17).

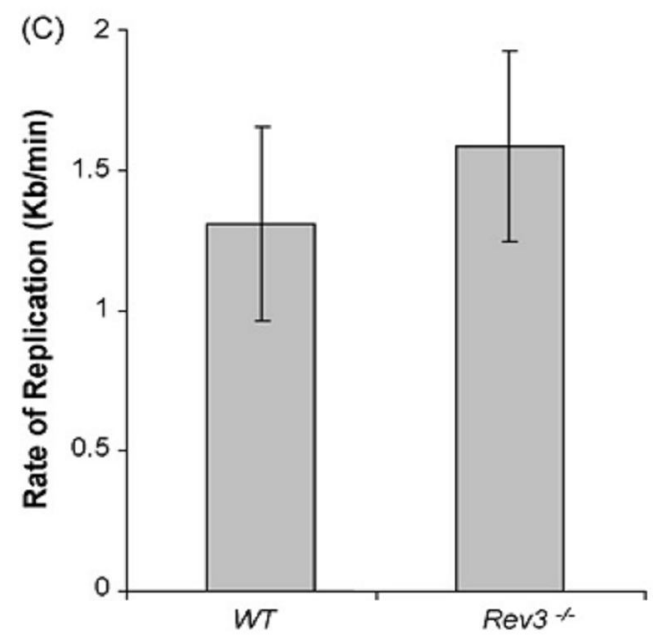

Figure 17. Replication rate in unexposed wild type and Rev $3^{-1-}$ MEFs calculated from IdU tracts extended for $20 \mathrm{~min}$.

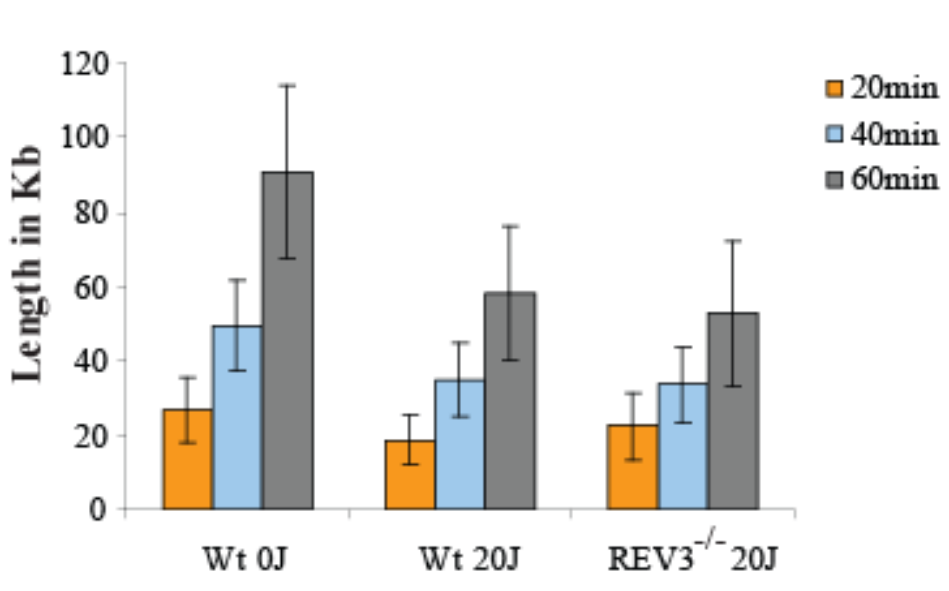

Figure 18. Length of replication forks during BrdU labeling in unexposed wild type cells and in wild type and Rev3 ${ }^{-1-}$ MEFs, 20, 40 and 60 min after exposure to $20 \mathrm{~J} / \mathrm{m}^{2} \mathrm{UV}-\mathrm{C}$. The error bars represent standard deviation.

Although the reason for this marginally faster fork progression in the Rev3 deficient cell line is unknown, our result indicates that Rev3 is dispensable for replication of undamaged templates. When wild type 
cells were treated with $20 \mathrm{~J} / \mathrm{m} 2 \mathrm{UV}-\mathrm{C}$, the average fork progression was only slightly reduced compared with unexposed cells and this reduction persisted for at least $60 \mathrm{~min}$ after exposure. This result indicates that the immediate bypass of photo-products is quite efficient in wild type cells. Unlike Rev1-deficient MEFs, in Rev3-deficient MEFs fork progression on UV-damaged DNA was not significantly delayed as compared to the wild type cells (Figure 16, 18, 19). Thus, by analyzing the distribution of the tract length ratio of IdU to BrdU we found no significant difference between Rev3-deficient and wild type cell lines (Figure 18), in contrast to the difference between Rev1-deficient and wild type cell lines. Indeed, calculating the average fork progression on UV-damaged DNA revealed that in Rev3-deficient MEFs there was no more delay than in the wild type cells. From these results we conclude that mammalian Rev3 is completely dispensable for immediate lesion bypass.

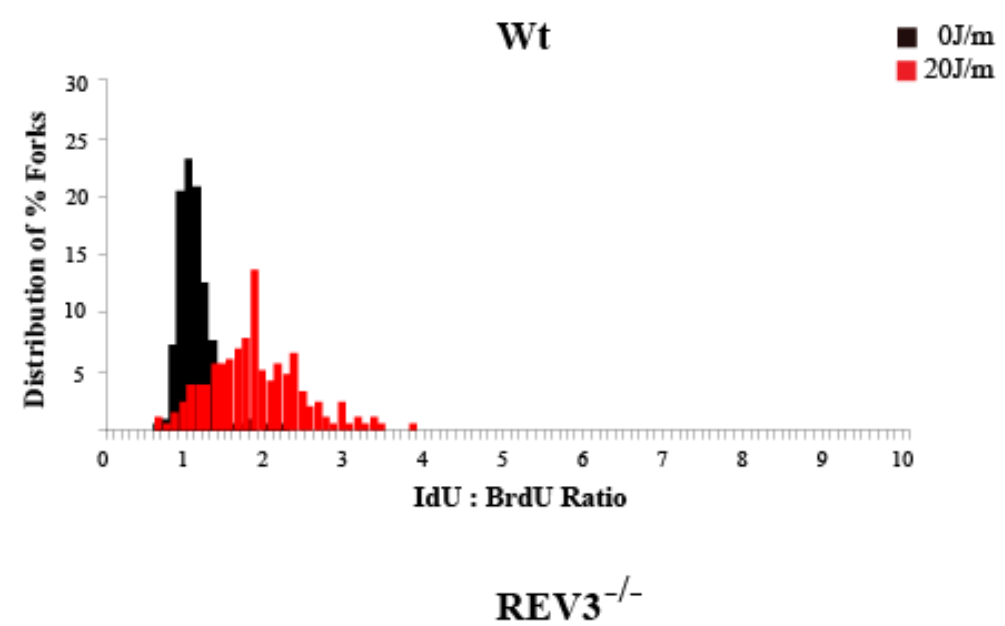

Figure 19. Distribution of percentage of replication forks at corresponding IdU:BrdU ratio during $20 \mathrm{~min}$ pulse labeling of each base analogue. Black bars, $0 \mathrm{~J} / \mathrm{m}^{2} \mathrm{UV}-\mathrm{C}$; red bars, $20 \mathrm{~J} / \mathrm{m}^{2} \mathrm{UV}$ C.

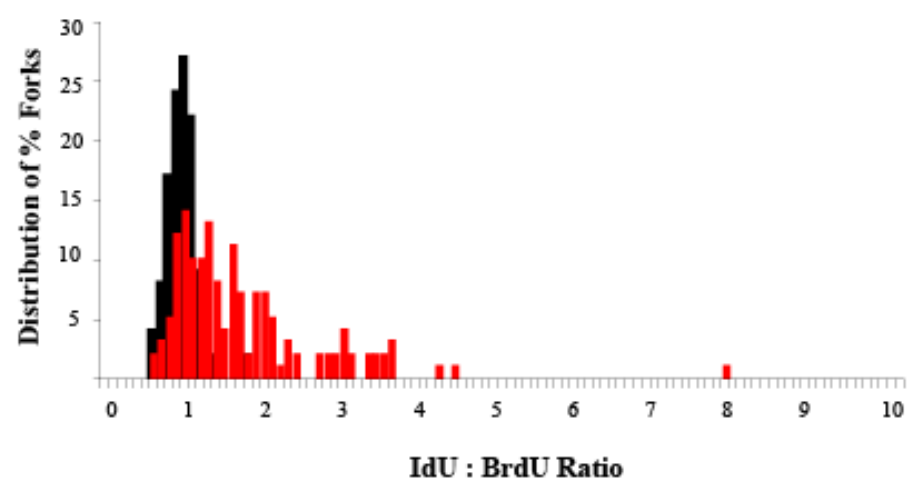




\subsection{SUMO modification of human PCNA}

To test directly for SUMOylation of human PCNA, we transiently co-expressed HA-tagged PCNA with FLAG-tagged SUMO1, SUMO2 or SUMO3 in human cells, and then performed FLAG immunoprecipitations. Western immunoblotting of the resulting samples with anti-HA antibody established that PCNA was indeed SUMOylated (Figure 20). Notably, we detected two higher mobility shifts suggesting at least two potential SUMOylation sites in human PCNA, and although SUMO1 predominantly conjugated to PCNA weak attachment of SUMO2 and SUMO3 was also detectable. Furthermore, the SUMOylation of PCNA did not require exogenous DNA damage.

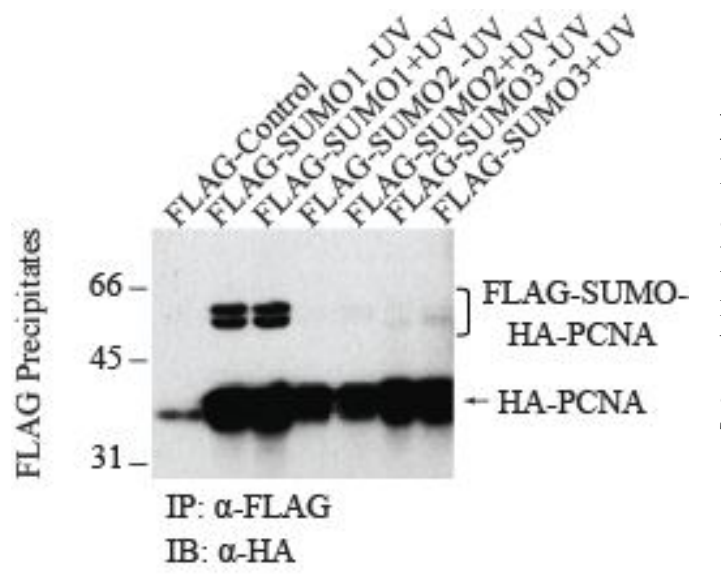

Figure 20. In vivo SUMO modification of human PCNA. HEK293T cells were co-transfected with HA-PCNA, His-UBC9, and either FLAG-SUMO1, or FLAG-SUMO2, or FLAG-SUMO3. In $48 \mathrm{~h}$ post-transfection cells were UV-treated $\left(30 \mathrm{~J} / \mathrm{m}^{2}\right)$ or mockirradiated and, after $3 \mathrm{~h}$ lysed and immunoprecipitated on FLAGbeads. FLAG-SUMO precipitates were immunoblotted with anti-HA antibody to detect PCNA and the SUMO-modified forms of PCNA. The lower panel shows the anti-HA Western-blot of the lysates.

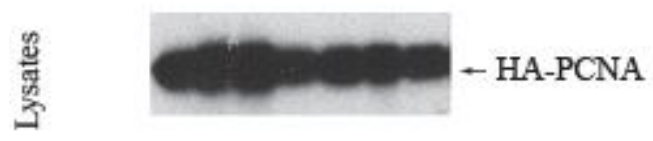

IB: $\alpha-\mathrm{HA}$

Also, we tested for the SUMO1 acceptor residues in human PCNA by mutating the highly conserved lysine 164 residue the main SUMO acceptor residue of yeast PCNA, to arginine, which indeed eliminated one of the main SUMOylated PCNA species (Figure 21). Nevertheless, similar experiments using all 16 single lysine mutant PCNAs did not help to unambiguously define the other SUMO attachment sites in PCNA (data not shown), presumably because SUMOylation of its different acceptor lysine residues can give rise to similar mobility PCNA shifts. 


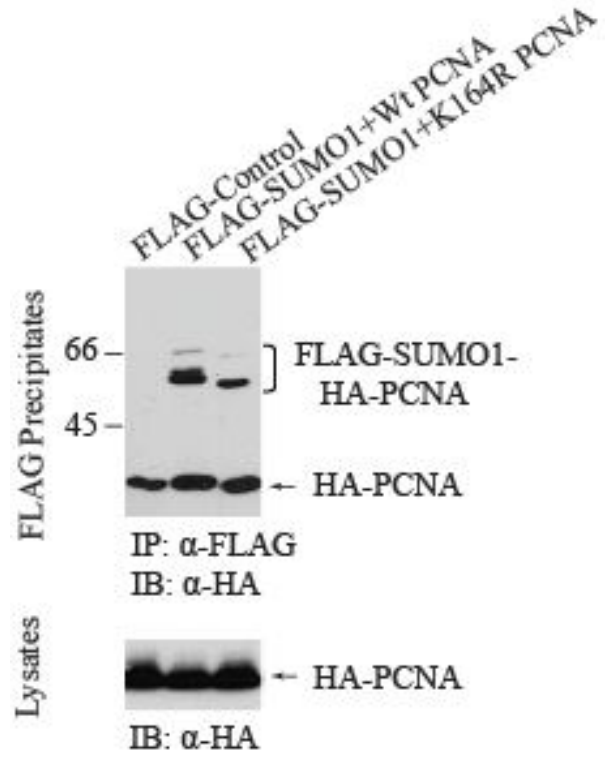

Figure 21. HEK293T cells were co-transfected with FLAGSUMO1, His-UBC9, and either HA-PCNA or K164R PCNA and 48 $\mathrm{h}$ post-transfection cells were lysed and immunoprecipitated on FLAG-beads. FLAG-SUMO1 precipitates were immunoblotted with anti-HA antibody to detect the effect of the K164R mutation on the SUMOylation of PCNA.

To further characterize, we set up an in vitro PCNA SUMOylation system using purified E1 SUMOactivating enzyme (SAE1/SAE2), E2 SUMO-conjugating enzyme (Ubc9), various E3 SUMO-ligases (Pias1, Pias2, Pias3, and Pias4) and all three SUMO isoforms (SUMO1, SUMO2, and SUMO3) (Figure $22,23)$.
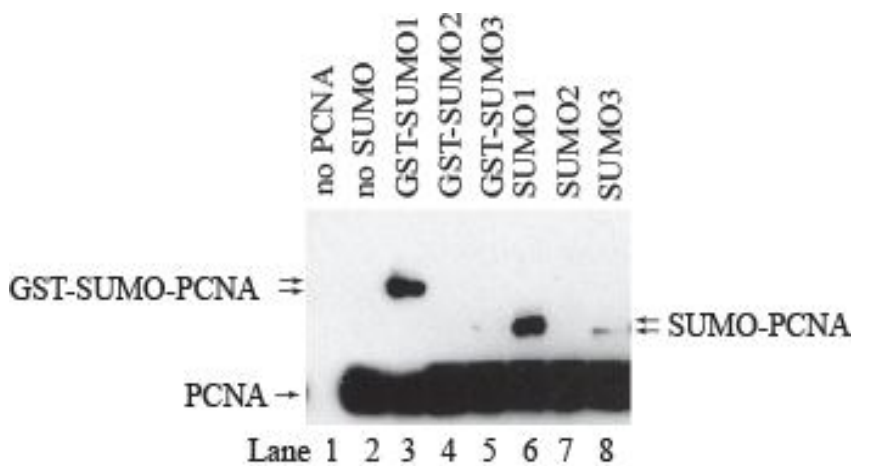

Figure 22. In vitro SUMO modification of human PCNA. In vitro SUMOylation reaction of human PCNA (40 nM) was carried out in the presence of purified SAE1/2 (10 $\mathrm{nM})$, Ubc9 (100 nM), RFC (10 nM) nicked PUC19 plasmid DNA (2 nM) and either GST-SUMO1, or GSTSUMO2, or GST-SUMO3, or SUMO1, or SUMO2, or SUMO3 (500 nM) at $37^{\circ} \mathrm{C}$ for $60 \mathrm{~min}$. Samples containing unmodified and SUMOylated PCNA were separated on $10 \%$ denaturing polyacrylamide gel and visualized by Western blot by using anti-PCNA antibody.

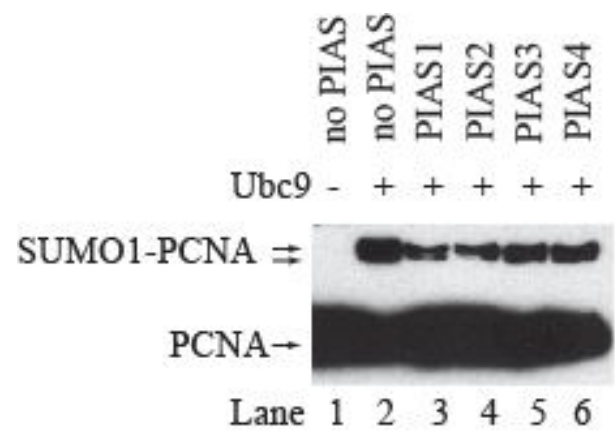

Figure 23. PCNA was subjected to in vitro SUMOylation reaction in the absence or presence of PIAS1, PIAS2, PIAS3 or PIAS4 (100 $\mathrm{nM}$ ) under the conditions described in Figure 22. 
Consistently with the in vivo findings, we established that out of three SUMO isoforms only SUMO1 could be efficiently conjugated to PCNA and that lysine 164 residue of PCNA was one of the main SUMO attachment site (Figure 25). In addition, using surface lysine mutant PCNAs (Figure 24) we managed to identify K254 residue as a second SUMOylation site in PCNA that locates in a consensus $\Psi \mathrm{KxE}$ SUMO attachment site, where $\Psi$ is an aliphatic residue (Figure 25). Consistently with alternate lysine modifications that we concluded from our in vivo experiments, at higher enzyme concentrations new SUMO-PCNA shifts also became apparent, particularly for certain lysine mutants (Figure 25).
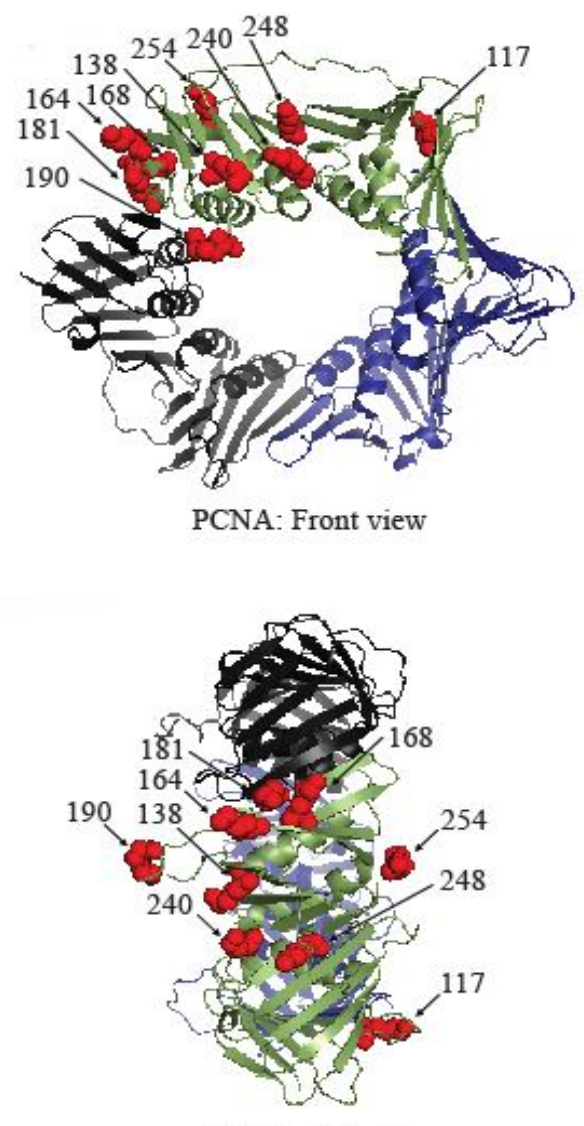

PCNA: Side view

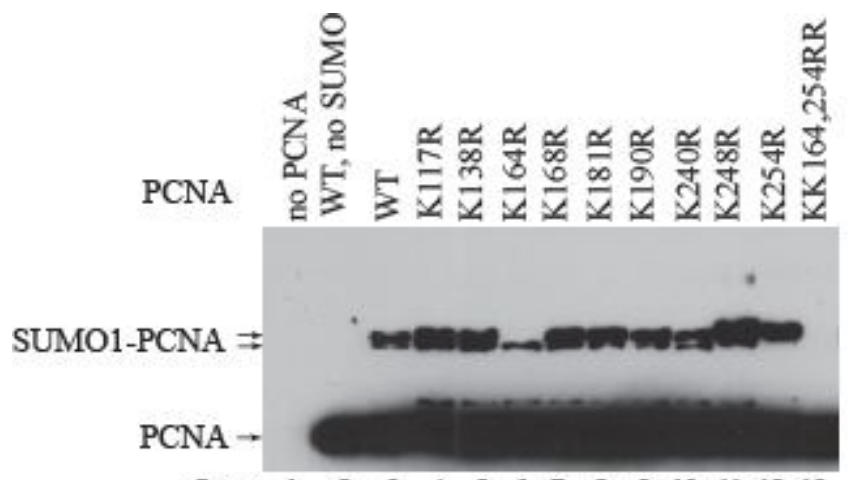

Lane $\begin{array}{lllllllllllll}1 & 2 & 3 & 4 & 5 & 6 & 7 & 8 & 9 & 10 & 11 & 12 & 13\end{array}$

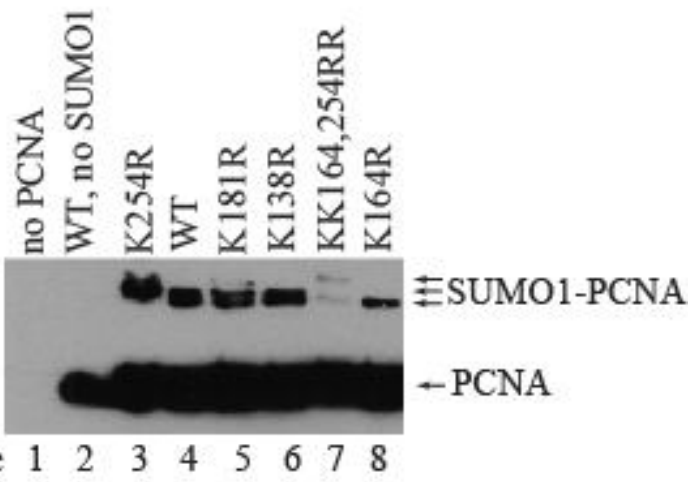

Lane $\begin{array}{llllllll}1 & 2 & 3 & 4 & 5 & 6 & 7 & 8\end{array}$

Figure 25. Wild-type and lysine point-mutant PCNA samples were subjected to in vitro SUMOylation reaction as described above.

Figure 24. Structure of human PCNA from the front (B) and side (C) views; surface lysine residues are represented by red spheres (K117, K138, K164, K168, K181, K190, K240, K248 and K254). PCNA structures showing the surface lysine residues were generated using the PyMOL version 0.96 by DeLano scientific (http.//www.pymolsourceforge.net). 
Strikingly, PCNA SUMOylation was dependent on replication factor C (RFC) (Figure 26), but did not require any of the four PIAS E3 ligases (Figure 23). Moreover, comparing PCNA SUMOylation to ubiquitylation in presence of RFC, nicked plasmid DNA or their combination revealed that in contrast to ubiquitylation which requires RFC-dependent loading of PCNA onto DNA, PCNA SUMOylation was only RFC but not DNA dependent. Thus interaction between PCNA and RFC is a prerequisite for PCNA SUMOylation presumably by exposing residues in PCNA or giving access for Ubc9.

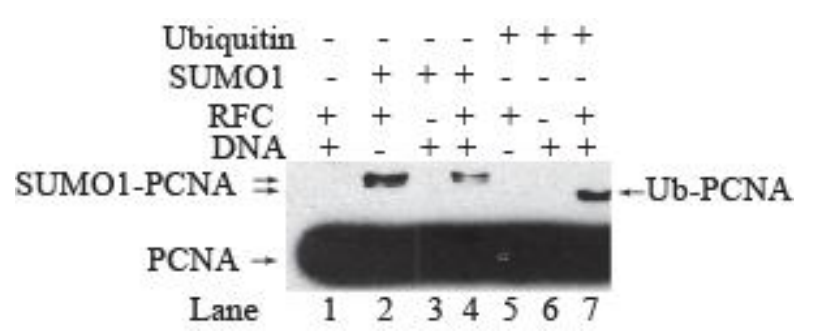

Figure 26. In vitro SUMOylation and ubiquitylation reactions of PCNA were compared in the absence or presence of combinations of RFC and nicked plasmid DNA as indicated.

To directly investigate the role of SUMO modification of human PCNA, we sought to generate a Cterminal fusion of SUMO1 to PCNA resulting in a PCNA-SUMO1 conjugate, a known strategy used to study the effect of SUMOylation of target proteins (Figure 27A).

A.

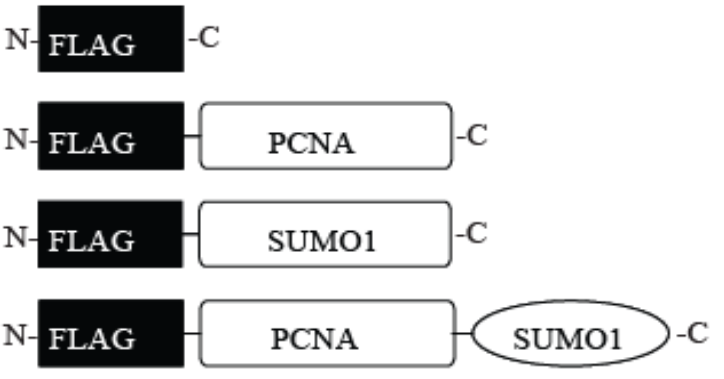

B.

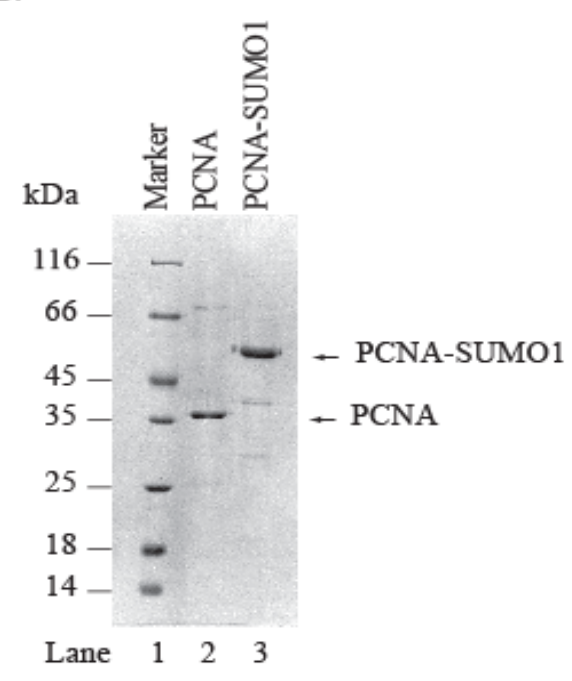

Figure 27. (A) Schematic representation of the fusion of SUMO1 at the C-terminus of a FLAG-tagged PCNA and the control vectors expressing only FLAG, FLAG-SUMO1, or FLAG-PCNA. (B)Purified human PCNA and human PCNA-SUMO1 fusion proteins were analyzed on 10\% polyacrylamide gel by Coomassie staining. 
Purified PCNA and PCNA-SUMO1 chimera (Figure 27B) were proficient in ubiquitylation reaction and localized to replication foci similarly to PCNA, corroborating the functionality of the PCNA-SUMO1 chimera (Figure 28, 29, 30). In addition, comparing flow cytometric profiles of stable cell lines expressing PCNA or PCNA-SUMO1 confirmed that PCNA-SUMO1 did not influence the cell cycle (Figure 30, 31).

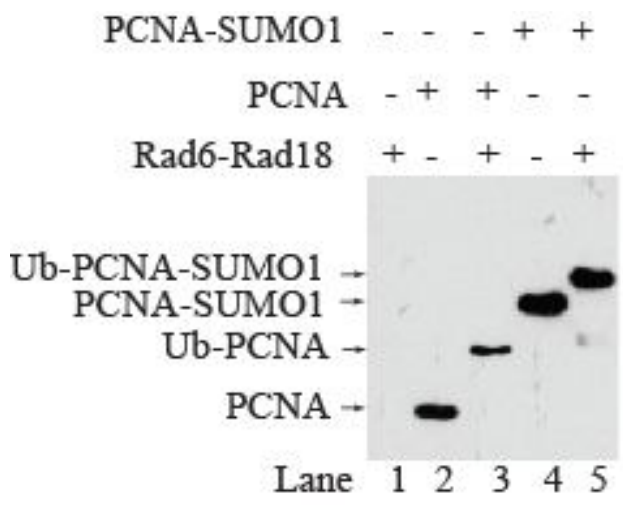

Figure 28. PCNA-SUMO1 fusion protein is proficient for ubiquitylation. PCNA and PCNA-SUMO1 were assayed for ubiquitylation in vitro in the presence of purified ubiquitin, Uba1, Rad6-Rad18, RFC, and DNA followed by Western blotting using anti PCNA antibody.

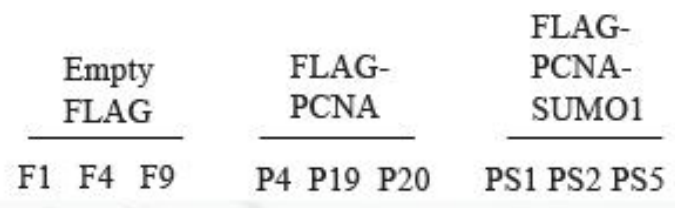

IB : $\alpha$ - PCNA
- FLAG-PCNASUMO1

- FLAG-PCNA

- Endogenous PCNA
Figure 29. Immunoblot with anti-PCNA antibody showing the expression of endogenous PCNA and the respective PCNA forms in three different HeLa cell clones each stably expressing FLAG (cell lines: F1, F4, F9), FLAG-PCNA (cell lines: P4, P19, P20) or FLAG-PCNA-SUMO1 (cell lines: PS1, PS2, PS5).

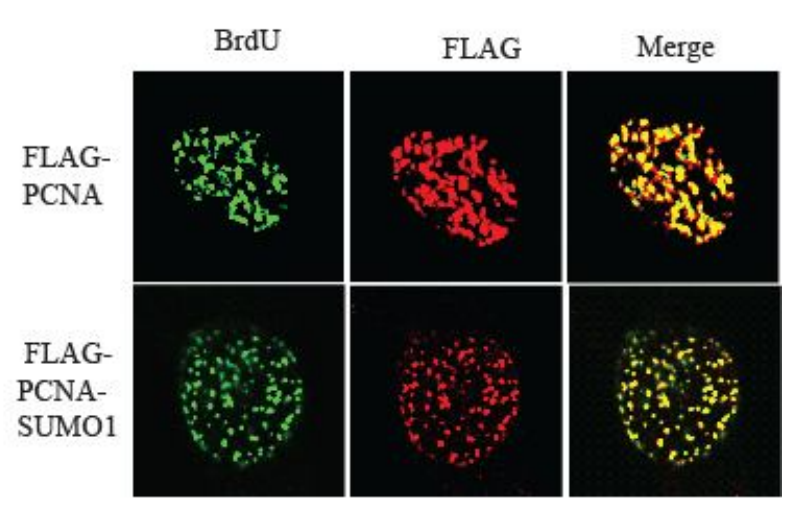

Figure 30. HeLa cells stably expressing FLAG-PCNA and FLAG-PCNA-SUMO1 were pulse labeled with $10 \mu \mathrm{M}$ BrdU for $1 \mathrm{~h}$ and immunostained with antibodies against FLAG (red) and BrdU (green). 


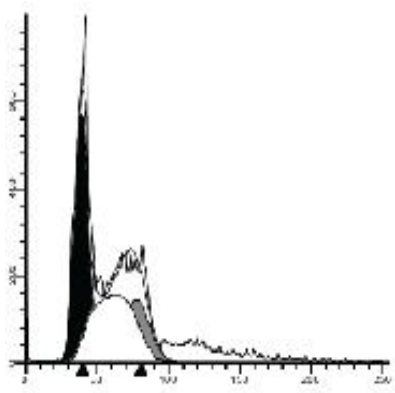

FLAG-Control

G1 \% : 39.5

$\mathrm{S} \%: 35.5$

G2/M \% : 25

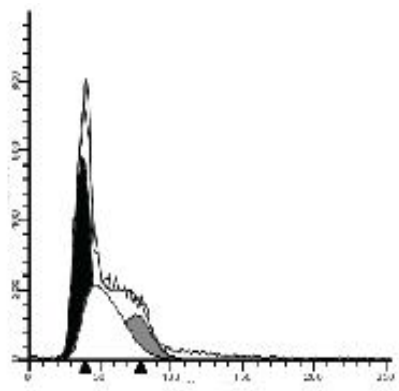

FLAG-PCNA

G1 \% : 44

$\mathrm{S} \%: 35$

G2/M \% : 21

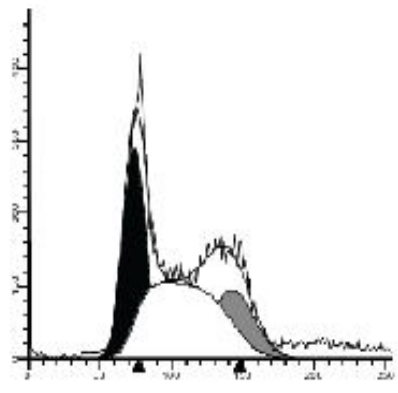

FLAG-PCNA-SUMO1

G1 \% : 35

$\mathrm{S} \%: 40$

G2/M \% : 25
Figure 31. Stable cell lines expressing FLAG-control, FLAG-PCNA and FLAG-PCNASUMO1 were subjected to flow cytometric analysis. Cell number is plotted on the $y$ axis; DNA content on the $x$ axis. Black, G1 peak; grey, G2/M peak; white, S phase fraction.

To measure the effect of the SUMO modification of PCNA on the rate of homologous recombination we employed a chromosomally integrated reporter system which measures the reconstituted expression of neomycin as events of homologous recombination. Supporting the findings in yeast studies, the expression of PCNA-SUMO1 conjugate in human cells significantly lowered the rate of I-SceI-generated DSB induced homologous recombination which indicated that SUMO modification of human PCNA can control recombination (Figure 32).

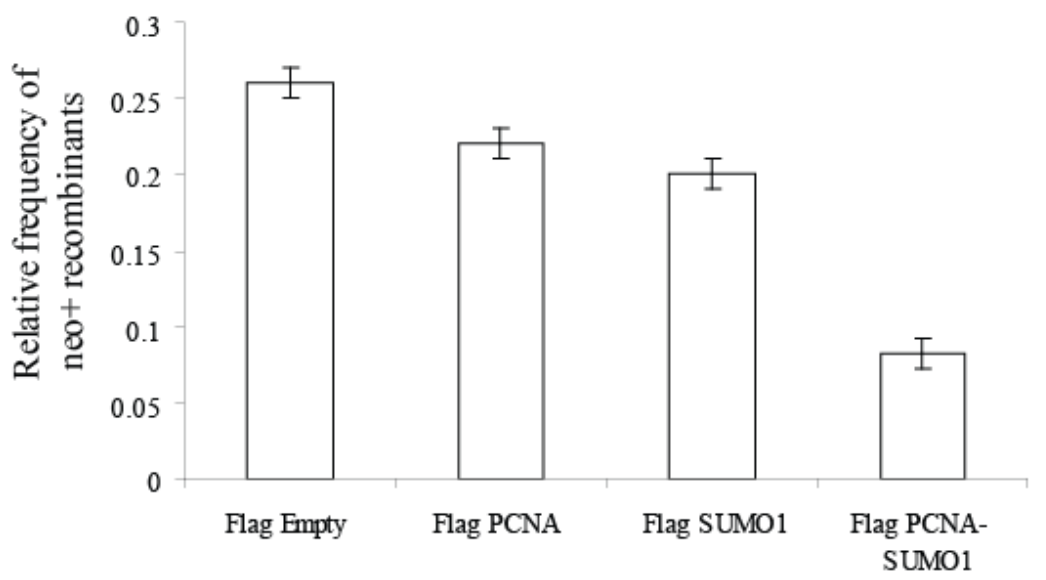

Figure 32. Effect of PCNA-SUMO1 fusion protein on homologous recombination. ISCeI induced recombinations were measured as $\mathrm{NeO}$ positive colonies after expressing control FLAG, FLAG-PCNA, FLAG-SUMO1 or FLAG-PCNA-SUMO1. Error bars show standard deviation of the data obtained from three independent experiments. 


\section{Discussion}

In the current PhD study I investigated the role of UBZ and PIP domains of Polymerase Eta in its accumulation at the replication foci, the role of Rev1 and Rev3 in the bypass of UV lesion in mammalians cells and the conservation of SUMO-PCNA dependent mechanisms in human cells.

Based on previous studies with hPol $\eta$, the proposal has been made that hPol $\eta$ and other Y family TLS Pols bind PCNA at 2 sites, the IDCL, which they bind by their PIP domain, and K164-linked Ub, which they bind via their UBZ domain, and that the binding of the Ub moiety on PCNA by the UBZ domain is essential for Pol's localization in replication foci and its function in TLS in vivo (Bienko et al 2005, Kannouche P et al 2004). The key point of this model is that it assigns a function to the Ub moiety on PCNA in the direct binding of hPol $\eta$ and other TLS Pols and postulates that this binding is mediated by the UBD of the TLS Pol. An alternative possibility, however, is that hPol $\eta$ and other TLS Pols bind PCNA only at the IDCL and the Ub moiety on PCNA plays no significant role in binding directly to the TLS Pol; rather, when the progressively moving replicative Pol stalls at a DNA lesion, the K164-linked Ub moiety effects a conformational change in PCNA, which enables the TLS Pol to bind PCNA at the IDCL and take over synthesis from the replicative Polymerase. Hence, the indispensable role of the Ub moiety on PCNA would then be in promoting the Polymerase exchange process. We discuss the implications of our observations with the hPol $\eta$ PIP and UBZ domains for these alternate models. Here, we provide evidence that the reason for the lack of an absolute requirement of the hPol $\eta$ PIP domain is the presence of an additional PIP domain in this protein. In addition to the previously identified Cterminal PIP domain, hPol $\eta$ harbors another PIP domain situated just after the PAD domain; we refer to these domains as PIP2 and PIP1, respectively. The mutational inactivation of either domain shows evidence of co-localization with PCNA in replication foci in UV-irradiated cells, the accumulation of hPol $\eta$ in replication foci and its coincident localization with PCNA do not occur for the PIP1, PIP2 double mutant. These data together with the observations that K164-linked Ub moiety on PCNA does not 
increase the proficiency of hPol $\eta$ for PCNA binding; mutational inactivation of the UBZ domain has no adverse effect on the stimulation of the DNA synthetic activity of hPol $\eta$ with PCNA or Ub-PCNA; the UBZ domain makes no significant contribution to hPol ๆ's PCNA binding (Acharya et al 2008), we conclude that the PIP1 and PIP2 domains can functionally substitute for one another. An important implication of these results is that hPol $\eta$ 's binding to PCNA via its PIP domain is essential for its ability to access PCNA and carry out TLS in human cells.

The DNA fiber assay is a powerful method to study the progression of replicons on individual DNA molecules early after DNA damage treatment (Jackson and Pombo 1998). We have investigated the role of Rev1 in the bypass of UV lesions in mammalian cells. We found that in UV-exposed Rev1deficient MEFs, progression of replicons is severely compromised, resulting in the generation of DNA molecules that are not converted into high molecular weight and that Rev1 BRCT domain is specifically required for efficient progression of stalled forks early after UV exposure suggesting the role of Rev1 in a relatively early DNA damage bypass pathway that might involve an interaction with monoubiquitinated PCNA, possibly mediated by interaction with the N-terminal BRCT domain of Rev1. On the other hand studies aiming to investigate the role of Rev3 in DNA damage response following UV exposure indicated normal fork progression in Rev3 deficient MEFs. This argues against a role of Rev3 in an immediate mode of damage bypass at photoproducts. Although DNA fiber assay does not discriminate between the direct extension of stalled forks and early translesion synthesis by filling of postreplicative gaps, the assay indicated that both Rev1 mutants are deficient in the extension of stalled forks where as Rev3 mutant showed normal fork progression within $1 \mathrm{~h}$ after UV treatment. However, alkaline sucrose gradient sedimentation that measures the maturation of nascent DNA indicates that replication fork stalling is more severe in Rev3-defective MEFs than in Rev1-defective MEFs (Jansen et al 2009a, Jansen et al 2009b). Together from these observations we conclude that Rev1 is required for bypass of DNA lesions both in immediate and late, post-replicative, modes where as Rev3 is essential for DNA damage tolerance by post-replicative gap filling. 
Replication fork collapse can result in structures that resemble recombination intermediates, responsible for the generation of genome rearrangements (Cotta-Ramusino et al 2005; Sogo et al 2002; Cha and Kleckner 2002). In order to escape the events that lead to genome instability and cancer-prone disorders, cells may have evolved mechanisms to regulate replication fork collapse and to prevent inappropriate recombination. Previous studies in yeast provide evidence for the role of SUMO-PCNA and Srs2, while studies in other higher eukaryotes established the involvement of RECQ helicases like BLM and RECQL5 functioning similar to yeast Srs2 in regulating recombination (Pfander et al 2005; Hu et al 2007; Bugreev et al 2007). Additionally, RTEL1 and FBH1 have also been implicated in the regulation of recombination as the functional homologues of yeast Srs2 (Barber et al 2008; Fugger et al 2009). However, the occurrence of PCNA SUMOylation in human cells remained elusive and has been thought to operate only in eukaryotic cells with a naturally high rate of recombination such as yeast. Only recently, SUMOylation of human PCNA has also been found and shown in a parallel study where PCNASUMO preferencially interacts with a PCNA interacting protein (PARI) to suppress inappropriate recombination events at the replication fork; however, the direct role of SUMO modification of human PCNA has not been studied (Moldovan et al 2012). Both in vitro and in vivo experiments in this study demonstrate the SUMOylation of human PCNA with all three SUMO paralogues, with SUMO1 being predominant. We revealed that PCNA SUMOylation depends on RFC, suggesting the importance of the presence of PCNA in a replication ensemble for its SUMOylation to occur. Also attachment of SUMO to PCNA lowered I-SceI-generated DSB-induced recombination. Our results support the conservation of the yeast SUMO-PCNA dependent mechanisms in human cells, and in this regard, they raise new questions including if the human RTEL1 and FBH1, predicted to be functional homologues of yeast Srs2, can also interact with PCNA-SUMO and facilitate disruption of Rad51 nucleoprotein filaments. 


\section{Summary of findings}

Some of the important findings obtained during the current thesis work are summarized as follows:

- The binding to PCNA via its PIP domain is a prerequisite for Poln's ability to function in TLS in human cells and that the direct binding of the Ub moiety on PCNA via its UBZ domain is not required.

- Rev1 plays a coordinating role in two modes of DNA damage bypass, i.e., an early and a late pathway. These studies reflect a role of the BRCT domain of Rev1 in mutagenic translesion synthesis. Rev1, but not its BRCT domain, is required for post-replication repair by gap filling, which dominates at a later stage.

- Rev3 is essential for a late mode of DNA damage tolerance whereas immediate translesion synthesis proceeds independently of Rev3.

- Human PCNA is predominantly modified by SUMO1 both in vivo and in vitro and regulates recombination frequency in vivo demonstrating the conservation and significance of the SUMO modification of PCNA in human cells. 


\section{References}

Acharya, N., R. E. Johnson, et al. (2006). Complex formation with Rev1 enhances the proficiency of Saccharomyces cerevisiae DNA polymerase zeta for mismatch extension and for extension opposite from DNA lesions. Mol Cell Biol 26(24): 9555-63.

Acharya N, et al. (2008) Roles of PCNA-binding and ubiquitin-binding domains in human DNA polymerase eta in translesion DNA synthesis. Proc Natl Acad Sci USA 105:17724-17729.

Arakawa H, Buerstedde J.M, et al (2006) A role for PCNA ubiquitination in immunoglobulin hypermutation, PLoS Biol. 4, e366.

Avkin S, Goldsmith M, Velasco-Miguel S, Geacintov N, Friedberg EC, Livneh Z (2004)Quantitative analysis of translesion DNA synthesis across a benzo[a]pyrene-guanine adduct in mammalian cells. The role of DNA polymerase $\kappa$. J Biol Chem 279: 53298-53305.

Ayyagari R, Impellizzeri KJ, Yoder BL, Gary SL, Burgers PM (1995) A mutational analysis of the yeast proliferating cell nuclear antigen indicates distinct roles in DNA replication and DNA repair. Mol Cell Biol 15: 4420-4429

Barber LJ, Youds JL, Ward JD, McIlwraith MJ, O'Neil NJ, Petalcorin MI, Martin JS, Collis SJ, Cantor SB, Auclair M, Tissenbaum H, West SC, Rose AM, Boulton SJ. (2008) RTEL1 maintains genomic stability by suppressing homologous recombination._Cell;135(2):261-71.

Barnes, D.E. \& Lindahl, T. (2004) Repair and genetic consequences of endogenous DNA base damage in mammalian cells. Annu Rev Genet 38, 445-76.

Barzilay G and Hickson ID (1995) Structure and function of apurinic/apyrimidinic endonucleases. Bioessays, 17, 713-719.

Bassett, E. et al. (2004) The role of DNA polymerase eta in translesion synthesis past platinum-DNA adducts in human fibroblasts. Cancer Research 64, 6469-6475.

Ben-Shahar, T.R. et al. (2009) Two Fundamentally Distinct PCNA Interaction Peptides Contribute to Chromatin Assembly Factor 1 Function. Molecular and Cellular Biology 29, 6353-6365.

Bi, X., D. M. Slater, et al. (2005). DNA polymerase kappa is specifically required for recovery from the benzo[a]pyrene-dihydrodiol epoxide (BPDE)-induced S-phase checkpoint. J Biol Chem 280(23): 22343-55.

Bienko M, et al. (2005) Ubiquitin-binding domains in Y-family polymerases regulate translesion synthesis. Science 310:1821-1824.

Bootsma D, Kraemer KH, Cleaver J, Hoeijmakers JHJ, In: B Vogelstein and KW Kinzler (ed) (1998) The Genetic basis of Human Cencer McGraw-Hill (New York): 254-274.

Bravo, R. \& Celis, J.E. (1982) Up-Dated Catalog of Hela-Cell Proteins -Percentages and 
Characteristics of the Major Cell Polypeptides Labeled with a Mixture of 16 C-14-Labeled AminoAcids. Clinical Chemistry 28,766.

Bruning, J.B. \& Shamoo, Y. (2004) Structural and thermodynamic analysis of human PCNA with peptides derived from DNA polymerase-delta p66 subunit and flap endonuclease-1. Structure 12, 2209-2219.

Budzowska, M. \& Kanaar, R. (2009) Mechanisms of Dealing with DNA DamageInduced Replication Problems. Cell Biochemistry and Biophysics 53, 17-31.

Bugreev DV, Yu X, Egelman EH, Mazin AV. (2007) Novel pro- and anti-recombination activities of the Bloom's syndrome helicase. Genes Dev.;21(23):3085-94.

Burgers, P. M. (1998) Eukaryotic DNA polymerases in DNA replication and DNA repair. Chromosoma 107(4): 218-27.

Burgers, P.M.J. \& Gerik, K.J. (1998) Structure and processivity of two forms of Saccharomyces cerevisiae DNA polymerase delta. Journal of Biological Chemistry 273, 19756-19762.

Burgers, P.M., and B.L. Yoder. (1993) ATP-independent loading of the proliferating cell nuclear antigen requires DNA ends. J Biol Chem 268(27): 19923-6.

Burgers, P.M.J. et al. (2001) Eukaryotic DNA polymerases: Proposal for a revised nomenclature. Journal of Biological Chemistry 276, 43487-43490.

C. Guo, P.L. Fischhaber, M.J. Luk-Paszyc, Y. Masuda, J. Zhou, K. Kamiya, C. Kisker, E.C. Friedberg.(2003) Mouse Rev1 protein interacts with multiple DNA polymerases involved in translesion DNA synthesis, EMBO J. 22 6621-6630.

Castrec, B. et al. (2009) Binding to PCNA in Euryarchaeal DNA Replication Requires Two PIP Motifs for DNA Polymerase D and One PIP Motif for DNA Polymerase B. Journal of Molecular Biology 394, 209-28.

Cha, R.S., and Kleckner, N. (2002). ATR homolog Mec1 promotes fork progression, thus averting breaks in replication slow zones. Science 297, 602-606.

Chilokova O, Stenlund P, Isoz I, Stith CM, Grabowski P, Lundstrom EB, Burgers PM, Johansson E. (2007) The eukaryotic leading and lagging strand DNA polymerases are loaded onto primer-ends via separate mechanisms but have comparable processitivity in the presence of PCNA. Nucleic Acids Res. 35(19):6588-97.

Cotta-Ramusino, C., Fachinetti, D., Lucca, C., Doksani, Y., Lopes, M., Sogo, J., and Foiani, M. (2005). Exo1 processes stalled replication forks and counteracts fork reversal in checkpoint-defective cells. Mol. Cell 17, 153-159.

Davey, M. J. and M. O'Donnell (2000) Mechanisms of DNA replication. Curr Opin Chem Biol 4 (5): 581-6.

de Saro, F.J.L. (2009) Regulation of Interactions with Sliding Clamps During DNA Replication and 
Repair. Current Genomics 10, 206-215.

Ducoux, M., S. Urbach, et al. (2001) Mediation of proliferating cell nuclear antigen (PCNA)dependent DNA replication through a conserved p21(Cip1)-like PCNA-binding motif present in the third subunit of human DNA polymerase delta. J Biol Chem 276(52): 49258-66.

Flores-Rosas H, Kelman Z, Dean FB, Pan Z, Harper JW, Elledge SJ, O'Donnell M and Hurwitz J. (1994). Proc. Natl. Acad. Sci. USA 91, 8655-8659.

Fousteri, M. \& Mullenders, L.H.(2008) Transcription-coupled nucleotide excision repair in mammalian cells: molecular mechanisms and biological effects. Cell Res 18, 73-84.

Frampton J, Irmisch A, Green CM, Neiss A, Trickey M, Ulrich HD, Furuya K, Watts FZ, Carr AM, Lehmann AR. (2006) Postreplication repair and PCNA modification in Schizosaccharomyces pombe, Mol. Biol. Cell 17, 2976-2985.

Friedberg EC, Bardwell AJ, Bardwell L, Feaver WJ, Kornberg RD, Svejstrup JQ, Tomkinson AE, Wang Z. (1995) Nucleotide excision repair in the yeast Saccharomyces cerevisiae: its relationship to specialized mitotic recombination and RNA polymerase II basal transcription. Philos Trans R Soc Lond B Biol Sci. 347(1319):63-8. Review.

Friedberg, E.C., Lehmann, A.R., and Fuchs, R.P. (2005). Trading places: how do DNA polymerases switch during translesion DNA synthesis? Mol Cell 18, 499-505.

Fugger K, Mistrik M, Danielsen JR, Dinant C, Falck J, Bartek J, Lukas J, Mailand N. (2009) Human Fbh1 helicase contributes to genome maintenance via pro- and anti-recombinase activities. J Cell Biol;186(5):655-63.

G.N. Gan, J.P. Wittschieben, B.Ø. Wittschieben, R.D. Wood. (2008) DNApolymerase zeta (pol zeta) in higher eukaryotes, Cell. Res. 18 174-183.

Gan, G. N., J. P. Wittschieben, et al. (2008). DNA polymerase zeta (pol zeta) in higher eukaryotes. Cell Res 18(1): 174-83.

Gerlach, V. L., L. Aravind, et al. (1999). Human and mouse homologs of Escherichia coli DinB (DNA polymerase IV), members of the UmuC/DinB superfamily. Proc Natl Acad Sci U S A 96(21): 11922-7.

Gibbs PE, McGregor WG, Maher VM, Nisson P and Lawrence CW (1998) A human homolog of the Saccharomyces cerevisiae REV3 gene, which encodes the catalytic subunit of DNA polymerase $\zeta$. Proc Natl Acad Sci USA, 95, 6876-6880.

Gibbs PE, Wang XD, Li Z, McManus TP, McGregor WG, Lawrence CW and Maher VM (2000) The function of the human homolog of Saccharomyces cerevisiae REV1 is required for mutagenesis induced by UV light. Proc Natl Acad Sci USA, 97, 4186-4191.

Gibbs, P. E., J. McDonald, et al. (2005). The relative roles in vivo of Saccharomyces cerevisiae Pol eta, Pol zeta, Rev1 protein and Pol32 in the bypass and mutation induction of an abasic site, T-T (6-4) photoadduct and T-T cis-syn cyclobutane dimer. Genetics 169(2): 575-82. 
Gulbis, J.M., Kelman, Z., Hurwitz, J., Odonnell, M. \& Kuriyan, J. (1996) Structure of the C-terminal region of p21(WAF1/CIP1) complexed with human PCNA. Cell 87, 297-306.

Guo C, et al. (2006) Ubiquitin-binding motifs in REV1 protein are required for its role in the tolerance of DNA damage. Mol Cell Biol 26:8892-8900.

Guo, C., Kosarek-Stancel, J.N., Tang, T.-S. \& Friedberg, E.C. (2009) Y-family DNA polymerases in mammalian cells. Cellular and Molecular Life Sciences 66, 2363-2381.

Guo, D.Y., Wu, X.H., Rajpal, D.K., Taylor, J.S. \& Wang, Z.G. (2001) Translesion synthesis by yeast DNA polymerase zeta from templates containing lesions of ultraviolet radiation and acetylaminofluorene. Nucleic Acids Research29, 2875-2883.

Haracska, L. et al. (2001b) Physical and functional interactions of human DNA polymerase eta with PCNA. Molecular and Cellular Biology 21, 7199-7206.

Haracska, L. et al. (2001c)Targeting of human DNA polymerase iota to the replication machinery via interaction with PCNA. Proceedings of the National Academy of Sciences of the United States of America 98, 14256-14261.

Haracska, L., Kondratick, C.M., Unk, I., Prakash, S. \& Prakash, L.(2001a) Interaction with PCNA is essential for yeast DNA polymerase eta function. Molecular Cell 8, 407-415.

Haracska, L. et al. (2001d) Roles of yeast DNA polymerases delta and zeta and of Rev1 in the bypass of abasic sites. Genes \& Development 15, 945-954.

Haracska, L., Prakash, L. \& Prakash, S. (2002) Role of human DNA polymerase kappa as an extender in translesion synthesis. Proceedings of the National Academy of Sciences of the United States of America 99, 16000-16005.

Haracska, L., Prakash, S. \& Prakash, L. (2003) Yeast DNA polymerase xi is an efficient extender of primer ends opposite from 7,8-dihydro-8-oxoguanine and O-6-methylguanine. Molecular and Cellular Biology 23, 1453-1459.

Haracska, L., N. Acharya, et al. (2005). A single domain in human DNA polymerase iota mediates interaction with PCNA: implications for translesion DNA synthesis. Mol Cell Biol 25(3): 1183-90.

Heyer WD (2004) Recombination: Holliday junction resolution and crossover formation. Curr Biol 14(2):R56-8

Hishiki, A. et al. (2009) Structural Basis for Novel Interactions between Human Translesion Synthesis Polymerases and Proliferating Cell Nuclear Antigen. Journal of Biological Chemistry 284, 10552-10560.

Hoege, C., Pfander, B., Moldovan, G.L., Pyrowolakis, G. \& Jentsch, S. (2002) RAD6-dependent DNA repair is linked to modification of PCNA by ubiquitin and SUMO. Nature 419, 135-141.

Hofmann R.M, Pickart C.M. (1999) Noncanonical MMS2-encoded ubiquitinconjugating enzyme 
functions in assembly of novel polyubiquitin chains for DNA repair, Cell 96, 645-653.

Hoeijmakers JHJ: (2001) Genome maintenance mechanisms for preventing cancer. Nature,411:366374.

Hu Y, Raynard S, Sehorn MG, Lu X, Bussen W, Zheng L, Stark JM, Barnes EL, Chi P, Janscak P, Jasin M, Vogel H, Sung P, Luo G. (2007) RECQL5/Recql5 helicase regulates homologous recombination and suppresses tumor formation via disruption of Rad51 presynaptic filaments. Genes Dev.;21(23):3073-84.

Hubscher, U., G.Maga, et al. (2002). Eukaryotic DNA polymerases. Annu Rev Biochem, 71, 133-63.

Jackson DA, Pombo A. (1998) Replicon clusters are stable units of chromosome structure: evidence that nuclear organization contributes to the efficient activation and propagation of $S$ phase in human cells. J Cell Biol;140(6):1285-95.

Jansen, J. G., A. Tsaalbi-Shtylik, et al. (2005). The BRCT domain of mammalian Rev1 is involved in regulating DNA translesion synthesis. Nucleic Acids Res 33(1): 356-65.

J.G. Jansen, A. Tsaalbi-Shtylik, G. Hendriks, H. Gali, A. Hendel, F. Johansson, K. Erixon, Z. Livneh, L.H. Mullenders, L. Haracska, N. de Wind, (2009a) Separate domains of Rev1 mediate two modes of DNA damage bypass in mammalian cells, Mol.Cell. Biol. 29, 3113-3123.

Jansen JG, Tsaalbi-Shtylik A, Hendriks G, Verspuy J, Gali H, Haracska L, de Wind N (2009b) Mammalian polymerase zeta is essential for post-replication repair of uv-induced dna lesions. DNA REPAIR 8 :(12). 1444-1451.

Jarosz DF, Godoy VG, Delaney JC, Essigmann JM, Walker GC (2006) A single amino acid governs enhanced activity of DinB DNA polymerases on damaged template. Nature 439: 225-228.

Jentsch, S., McGrath, J.P. \& Varshavsky, A. (1987) The Yeast DNA-Repair Gene Rad6 Encodes a Ubiquitin-Conjugating Enzyme. Nature 329, 131-134.

JJ Turchi and RA Bambara (1993) Completion of mammalian lagging strand DNA replication using purified proteins. J. Biol. Chem., Vol. 268, Issue 20, 15136-15141, 07.

Johnson RE, Prakash S and Prakash L (1999) Requirement of DNA polymerase activity of yeast Rad30 protein for its biological function. J Biol Chem, 274, 15975-15977.

Johnson, R.E., Prakash, S. \& Prakash, L. (1999a) Efficient bypass of a thyminethymine dimer by yeast DNA polymerase, Pol eta. Science 283, 1001-1004.

Johnson, R.E., Kondratick, C.M., Prakash, S. \& Prakash, L. (1999b) hRAD30 mutations in the variant form of xeroderma pigmentosum. Science 285, 263-265.

Johnson, N. P., Mazard, A. M., Escalier, J., and Macquet, J. P. (1985) Mechanism of the reaction between cis-[PtCl2(NH3)2] and DNA in vitro. J . Am. Chem. SOC. 107,6376-6380. 
Johnson RE, Washington MT, Haracska L, Prakash S, Prakash L. (2000). Eukaryotic polymerases iota and zeta act sequentially to bypass DNA lesions, Nature 406(6799): 1015-9.

Johnson, S.J. \& Beese, L.S. (2004) Structures of mismatch replication errors observed in a DNA polymerase. Cell 116, 803-816.

Jonsson, Z.O., Hindges, R. \& Hubscher, U. (1998) Regulation of DNA replication and repair proteins through interaction with the front side of proliferating cell nuclear antigen. Embo Journal 17, 24122425 .

Kannouche P, et al. (2001) Domain structure, localization, and function of DNA polymerase , defective in xeroderma pigmentosum variant cells. Genes Dev 15:158-172.

Kannouche P, Fernández de Henestrosa AR, Coull B, Vidal AE, Gray C, Zicha D, Woodgate R, Lehmann AR. (2003). Localization of DNA polymerases eta and iota to the replication machinery is tightly coordinated in human cells. Embo J 21(22): 6246-56.

Kannouche P, Wing J, Lehmann AR (2004) Interaction of human DNA polymerase eta with monoubiquitinated PCNA: A possible mechanism for the polymerase switch in response to DNA damage. Mol Cell 14:491-500.

Kolodner R. (1996) Biochemistry and genetics of eukaryotic mismatch repair.Genes \& Dev.10:14331442.

Krogh, B.O. and Symington, L.S. 2004. Recombination proteins in yeast. Annu. Rev. Genet. 38: 233271.

Kunkel, T.A. \& Burgers, P.M. (2008) Dividing the workload at a eukaryotic replication fork. Trends in Cell Biology 18, 521-527.

Lawrence, C. W. and V. M. Maher (2001). Mutagenesis in eukaryotes dependent on DNA polymerase zeta and Rev1p. Philos Trans R Soc Lond B Biol Sci 356(1405): 41-6.

Lawrence, C. W. (2004). Cellular functions of DNA polymerase zeta and Rev1 protein. Adv Protein Chem 69: 167-203.

Leach CA, Michael WM. (2005) Ubiquitin/SUMO modification of PCNA promotes replication fork progression in Xenopus laevis egg extracts, J. Cell Biol. 171 947-954.

Lee K.Y, Myung K. (2008) PCNA modifications for regulation of post-replication repair pathways. Mol. Cells 26, 5-11.

Lee, D.H. \& Pfeifer, G.P. (2008) Translesion synthesis of 7,8-dihydro-8-oxo-2 '- deoxyguanosine by DNA polymerase eta in vivo. Mutation ResearchFundamental and Molecular Mechanisms of Mutagenesis 641, 19-26.

Lehmann, A.R. et al. (2007) Translesion synthesis: Y-farnily polymerases and the polymerase switch. DNA Repair 6, 891-899. 
Lewis LK and Resnick MA (2000) Tying up loose ends: nonhomologous end-joining inSaccharomyces cerevisiae. Mutagen Res, 451, 71-89.

Lindahl, T. (1993) Instability and Decay of the Primary Structure of DNA. Nature, 362, 709-715.

Lindahl, T. \& Barnes, D.E. (2000) Repair of endogenous DNA damage. Cold Spring Harb Symp Quant Biol 65, 127-33.

Lone, S. et al. (2007) Human DNA polymerase kappa encircles DNA: Implications for mismatch extension and lesion bypass. Molecular Cell 25, 601-614.

Longley MJ, Pierce AJ, Modrich P (1997) DNA polymerase d is required for human mismatch repair in vitro. J Biol Chem 272:10917-10921.

Maga, G. \& Hubscher, U. (2003) Proliferating cell nuclear antigen (PCNA): a dancer with many partners. Journal of Cell Science 116, 3051-3060 .

Masutani, C. et al. (1999) The XPV (xeroderma pigmentosum variant) gene encodes human DNA polymerase eta. Nature 399, 700-704.

Masutani C, Kusumoto R, Iwai S and Hanaoka F (2000) Mechanisms of accurate translesion synthesis by human DNA polymerase $\square$ EMBO J, 19, 3100-3109.

McCulloch SD, Kokoska RJ, Masutani C, Iwai S, Hanaoka F, Kunkel TA (2004)Preferential cis-sin thymine dimer bypass by DNA polymerase $\square$ occurs with biased fidelity. Nature 428: 97-100

McCulloch, S.D. \& Kunkel, T.A. (2008) The fidelity of DNA synthesis by eukaryotic replicative and translesion synthesis polymerases. Cell Research 18, 148-161.

McDonald, J.P., Levine, A.S. \& Woodgate, R. (1997) The Saccharomyces cerevisiae RAD30 gene, homologue of Escherichia coli dinB and umuC, is DNA damage inducible and functions in a novel error-free postreplication repair mechanism. Genetics 147, 1557-1568.

Mohindra A, Hays LE, Phillips EN, Preston BD, Helleday T, Meuth M. (2002) Defects in homologous recombination repair in mismatch-repair-deficient tumour cell lines. Hum Mol Genet.;11(18):2189-200.

Moldovan, G.L., Pfander, B. \& Jentsch, S. (2007) PCNA, the maestro of the replication fork. Cell 129, 665-679.

Moldovan GL, Dejsuphong D, Petalcorin MI, Hofmann K, Takeda S, Boulton SJ, D'Andrea AD. (2012) Inhibition of homologous recombination by the PCNA-interacting protein PARI. Mol.Cell 45(1):75-86.

Morrison,A., Araki,H., Clark,A.B., Hamatake,R.K. and Sugino,A. (1990) A third essential DNA polymerase in S. cerevisiae. Cell, 62, 1143-1151.

Mossi, R; Jónsson Z O, Allen B L, Hardin S H, Hübscher U (1997). Replication factor C interacts with the C-terminal side of proliferating cell nuclear antigen. J. Biol. Chem.272 (3): 1769-76. 
Motegi A, Liaw HJ, Lee KY, Roest HP, Maas A, Wu X, Moinova H, Markowitz SD, Ding H, Hoeijmakers JH, Myung K. (2008) Polyubiquitination of proliferating cell nuclear antigen by HLTF and SHPRH prevents genomic instability from stalled replication forks, Proc. Natl. Acad. Sci. U.S.A. $105,12411-12416$.

Motegi A, Sood R, Moinova H, Markowitz SD, Liu PP, Myung K. (2006) Human SHPRH suppresses genomic instability through proliferating cell nuclear antigen polyubiquitination, J. Cell Biol. 175, 703-708.

N.K. Acharya, R.E. Johnson, S. Prakash, L. Prakash. (2006) Complex formation with Rev1 enhances the proficiency of Saccharomyces cerevisiae DNA polymerase zeta for mismatch extension and for extension opposite from DNA lesions, Mol. Cell. Biol. 26 9555-9563.

Nair, D.T., Johnson, R.E., Prakash, S., Prakash, L. \& Aggarwal, A.K. (2004) Replication by human DNA polymerase-iota occurs by Hoogsteen basepairing. Nature 430, 377-380.

Nair, D.T., Johnson, R.E., Prakash, L., Prakash, S. \& Aggarwal, A.K. (2005) Rev1 employs a novel mechanism of DNA synthesis using a protein template. Science 309, 2219-2222.

Naryzhny, S.N. (2008) Proliferating cell nuclear antigen: a proteomics view. Cellular and Molecular Life Sciences 65, 3789-3808.

Nelson, J. R., P. E. Gibbs, et al. (2000). Evidence for a second function for Saccharomyces cerevisiae Rev1p. Mol Microbiol 37(3): 549-54.

Nick McElhinny SA, Gordenin DA, Stith CM, Burgers PM, Kunkel TA.(2008) Division of labor at the eukaryotic replication fork. Mol Cell;30(2):137-44.

O'Donnell, M. (2006) Replisome architecture and dynamics in Escherichia coli. Journal of Biological Chemistry 281, 10653-10656.

Ogi, T., Kannouche, P. \& Lehmann, A.R. (2005) Localisation of human Y-family DNA polymerase kappa: relationship to PCNA foci. Journal of Cell Scienc 118, 129-136.

Ogi, T., Shinkai, Y., Tanaka, K. and Ohmori, H. (2002). Pol $\kappa$ protects mammalian cells against the lethal and mutagenic effects of benzo[a]pyrene. Proc. Natl. Acad. Sci. USA 99, 15548-15553.

Ohashi, E., Y. Murakumo, et al. (2004). Interaction of hREV1 with three human Y-family DNA polymerases. Genes Cells 9(6): 523-31.

Pabla, R., Rozario, D. \& Siede, W. (2007) Regulation of Saccharomyces cerevisiae DNA polymerase eta transcript and protein. Environmental and Molecular Mutagenesis 48, 601-601.

Papouli, E. et al. (2005) Crosstalk between SUMO and ubiquitin on PCNA is mediated by recruitment of the helicase Srs2p. Molecular Cell 19, 123-133.

Parikh, S.S. et al. (1998) Base excision repair initiation revealed by crystal structures and binding kinetics of human uracil-DNA glycosylase with DNA. Embo J 17, 5214-26. 
Parker, J.L. et al. (2008) SUMO modification of PCNA is controlled by DNA. EMBO Journal 27, 2422-2431.

Pfander, B., Moldovan, G.L., Sacher, M., Hoege, C. and Jentsch, S. (2005) SUMO-modified PCNA recruits Srs2 to prevent recombination during $S$ phase. Nature, 436, 428-433.

Plosky BS, et al. (2006) Controlling the subcellular localization of DNA polymerases and via interactions with ubiquitin. EMBO J 25:2847-2855.

Prakash, S., Johnson, R.E. \& Prakash, L. (2005) Eukaryotic translesion synthesis DNA polymerases: Specificity of structure and function. Annual Review of Biochemistry 74, 317-353.

Prelich, G., C. K. Tan, et al. (1987) Functional identity of proliferating cell nuclear antigen and a DNA polymerase-delta auxiliary protein. Nature 326(6112): 517-20.

Prigent C, Satoh MS, Daly G, Barnes DE and Lindahl T (1994) Aberrant DNA repair and DNA replication due to an inherited enzymatic defect in human DNA ligase I. Mol Cell Biol, 14, 310-317.

Pursell ZF, Isoz I, Lundström EB, Johansson E, Kunkel TA (2007) Yeast DNA polymerase epsilon participates in leading-strand DNA replication. Science;317(5834):127-30.

Ramilo C, Gu L, Guo S, Zhang X, Patrick S.M, Turchi J.J, and Li G.M. (2002). Partial reconstitution of human DNA mismatch repair in vitro: characterization of the role of human replication protein A. Mol. Cell. Biol. 22, 2037-2046.

Roush, A.A., Suarez, M., Friedberg, E.C., Radman, M. \& Siede, W. (1998) Deletion of the Saccharomyces cerevisiae gene RAD30 encoding an Escherichia coli DinB homolog confers UV radiation sensitivity and altered mutability. Molecular and General Genetics 257, 686-692.

Sakurai, S. et al. (2005) Structural basis for recruitment of human flap endonuclease 1 to PCNA. Embo Journal 24, 683-693.

Scanar A.(1996a) No end of history for photolyases. Science, 272, 48-9.

Scanar A.(1996b) DNA excision repair. Annu Rev Biochem, 65, 43-81.

Scharer OD. (2003) Chemistry and biology of DNA repair. Angew Chem Int Ed Engl 42: 2946-2974.

Schofield, M.J., and Hsieh, P. (2003). DNA mismatch repair: molecular mechanisms and biological function. Annu. Rev. Microbiol. 57, 579-608.

Skoneczna, A., McIntyre, J., Skoneczny, M., Policinska, Z. \& SledziewskaGojska, E. (2007) Polymerase eta is a short-lived, proteasomally degraded protein that is temporarily stabilized following UV irradiation in Saccharomyces cerevisiae. Journal of Molecular Biology 366, 10741086. 
Simpson LJ, Ross AL, Szüts D, Alviani CA, Oestergaard VH, Patel KJ, Sale JE. (2006) RAD18independent ubiquitination of proliferating-cell nuclear antigen in the avian cell line DT40, EMBO Rep. 7, 927-932.

Sobol, R.W. \& Wilson, S.H. (2001) Mammalian DNA beta-polymerase in base excision repair of alkylation damage. Prog Nucleic Acid Res Mol Biol 68, 57-74.

Sogo, J.M., Lopes, M., and Foiani, M. Fork reversal and ssDNA accumulation at stalled replication forks owing to checkpoint defects.(2002). Science 297, 599-602.

Stelter, P. \& Ulrich, H.D. (2003) Control of spontaneous and damage-induced mutagenesis by SUMO and ubiquitin conjugation. Nature 425, 188-191.

Stucki, M., Z. O. Jonsson, et al. (2001) In eukaryotib flap endonuclease 1, the C-terminus is essential for substrate binding. J Biol Chem 276, 11, 7843-9.

Swan, M.K., Johnson, R.E., Prakash, L., Prakash, S. \& Aggarwal, A.K. (2009) Structural basis of high-fidelity DNA synthesis by yeast DNA polymerase delta. Nature Structural \& Molecular Biology 16, 979-U107.

Takenaka, K. et al. (2006) Involvement of vertebrate Pol kappa in translesion DNA synthesis across DNA monoalkylation damage. Journal of Biological Chemistry 281, 2000-2004.

Tanno, M., Ogihara, M. \& Taguchi, T. (1996) Age-related changes in proliferating cell nuclear antigen levels. Mechanisms of Ageing and Development 92, 53-66.

Tissier A, Frank EG, McDonald JP, Iwai S, Hanaoka F and Woodgate R (2000) Misinsertion and bypass of thymine-thymine dimers by human DNA polymerase 1. EMBO J, 19, 5259-5266.

Tissier, A., P. Kannouche, et al. (2004). Co-localization in replication foci and interaction of human Y-family members, DNA polymerase pol eta and REVl protein. DNA Repair (Amst) 3(11): 1503-14.

Trincao, J. et al. (2001) Structure of the catalytic core of S-cerevisiae DNA polymerase eta: Implications for translesion DNA synthesis. Molecular Cell 8, 417-426.

Ulrich H.D. (2005) The RAD6 pathway: control ofDNAdamage bypass and mutagenesis by ubiquitin and SUMO, ChemBiochem 6,1735-1743.

Ulrich H.D. (2007a) Conservation of DNA damage tolerance pathways from yeast to humans. Biochem. Soc.Trans. 35, 1334-1337.

Ulrich H.D. (2007b) PCNA-SUMO and Srs2: a model SUMO substrate-effector pair. Biochem. Soc. Trans. 35, 1385-1388.

Unk, I., Hajdu, I., Fatyol, K., Hurwitz, J., Yoon, J.H., Prakash, L., Prakash, S. and Haracska, L.(2008) Human HLTF functions as a ubiquitin ligase for proliferating cell nuclear antigen polyubiquitination. Proc.Natl.Acad.Sci.U.S.A, 105, 3768-3773. 
Unk, I., Hajdu, I., Fatyol, K., Szakal, B., Blastyak, A., Bermudez, V., Hurwitz, J., Prakash, L. Prakash, S. and Haracska, L. (2006) Human SHPRH is a ubiquitin ligase for Mms2-Ubc13-dependent polyubiquitylation of proliferating cell nuclear antigen. Proc.Natl.Acad.Sci.U.S.A, 103, 18107-18112.

Vidal, A.E. et al. (2004) Proliferating cell nuclear antigen-dependent coordination of the biological functions of human DNA polymerase iota. Journal of Biological Chemistry 279, 48360-48368.

Waga S, Bauer G, Stillman B. (1994) Reconstitution of complete SV40 DNA replication with purified replication factors. J Biol Chem, 269(14):10923-34.

Washington, M.T., Johnson, R.E., Prakash, S. \& Prakash, L. (1999) Fidelity and processivity of Saccharomyces cerevisiae DNA polymerase eta. Journal of Biological Chemistry 274, 36835-36838.

Washington, M.T., Johnson, R.E., Prakash, S. \& Prakash, L. (2000) Accuracy of thymine-thymine dimer bypass by Saccharomyces cerevisiae DNA polymerase eta. Proceedings of the National Academy of Sciences of the United States of America 97, 3094-3099.

Washington, M.T., Johnson, R.E., Prakash, L. \& Prakash, S. (2002) Human DINB1-encoded DNA polymerase kappa is a promiscuous extender of mispaired primer termini. Proceedings of the National Academy of Sciences of the United States of America 99, 1910-1914.

Washington, M.T. et al. (2004) Efficient and error-free replication past a minorgroove DNA adduct by the sequential action of human DNA polymerases iota and kappa. Molecular and Cellular Biology 24, 5687-5693.

Washington, M.T. et al. (2004a) Efficient and error-free replication past a minorgroove N-2-guanine adduct by the sequential action of yeast Rev1 and DNA polymerase zeta. Molecular and Cellular Biology 24, 6900-6906.

Washington, M.T., Carlson, K.D., Freudenthal, B.D. \& Pryor, J.M.(2009) Variations on a theme: Eukaryotic Y-family DNA polymerases. Biochim Biophys Acta.

Watanabe K, Tateishi S, Kawasuji M, Tsurimoto, Inoue T.H, Yamaizumi M. (2004)Rad18 guides pol to replication stalling sites through physical interaction and PCNA monoubiquitination, EMBO J. 23, 3886-3896.

Weterings, E. \& Chen, D.J. The endless tale of non-homologous endjoining. Cell Res 18, 114-24 (2008).Wold MS (1997) Replication protein A: a heterotrimeric, single-stranded DNA-binding protein required for eukaryotic DNA metabolism. Annu Rev Biochem, 66, 61-92.

Y. Masuda, M. Ohmae, K. Masuda, K. Kamiya. (2003) Structure and enzymatic properties of a stable complex of the human REV1 and REV7 proteins, J. Biol. Chem. 278 12356-12360.

Y. Murakumo, Y. Ogura, H. Ishii, S. Numata, M. Ichihara, C.M. Croce, T. Finkel, M. Takahashi. (2001) Interactions in the error-prone postreplication repair proteins hREV1, hREV3, and hREV7, J. Biol. Chem. 276 35644-35651.

Yao NY, Johnson A, Bowman GD, Kuriyan J, O'Donnell M.(2006) Mechanism of proliferating cell 
nuclear antigen clamp opening by replication factor C. J Biol Chem. 23;281(25):17528-39.

Yoder, B. L., and P. M. Burgers. (1991) Saccharomyces cerevisiae replication factor CI. Purification and characterization of its ATPase activity. J Biol Chem 266(33): 22689-97.

Yu, S.L., Johnson, R.E., Prakash, S. \& Prakash, L. (20001) Requirement of DNA polymerase eta for error-free bypass of UV-induced CC and TC photoproducts. Molecular and Cellular Biology 21, 185188.

Zhang P, Mo JY, Perez A, Leon A, Liu L, Mazloum N, Xu H \& Lee MY (1999) Direct interaction of proligerating cell nuclear antigen with the p125 catalytic subunit of mammalian DNA polymerase $\delta$. J Biol Chem 274: 26647-26653.

Zhang Y, Yuan F, Wu X, Wang Z. (2000). "Preferential incorporation of G opposite template T by the low-fidelity human DNA polymerase iota." Mol Cell Biol 20(19): 7099-108.

Zhuang, Z. \& Ai, Y. (2009) Processivity factor of DNA polymerase and its expanding role in normal and translesion DNA synthesis. Biochim Biophys Acta. 


\section{Acknowledgement}

When I look back, I am surprised with the years I spent on PhD study, but I am grateful for all that I have received, it certainly shaped me for the person I am and led me scientifically where I am now. These years of $\mathrm{PhD}$ provided me with wonderful experiences.

First and foremost I want to express my gratitude and thank my supervisor Dr. Haracska Lajos for providing the research opportunity in his group. I appreciate his invaluable time, guidance and funding. I benefited a lot from his knowledge and was a great experience working with him.

I also thank all the members of his Mutagenesis and carcinigenesis research group, Dr.Unk Ildiko and members of her DNA repair group for their friendly association in the research team; specially Illesne Kovacs Katalin, Fekete Ildiko and Notari Peterne for their extraordinary support.

I extend my thanks to Prof. Satya Prakash from the Department of Biochemistry and Molecular Biology, University of Texas Medical Branch and Dr. Niels de Wind from the Department of Toxicogenetics, Leiden University Medical Center for their successful scientific collaborations and publications.

I appreciate the time and effort of Blastyak Andras and Mates Lajos for reading my thesis and providing me constructive criticism to improve the quality of this thesis.

A special thanks to Vamsikrishna Gali and Yathish J Achar for always being by my side with their support. It was a pleasure to share my doctoral studies and life with these two wonderful people.

I would like to acknowledge for the support I received from the administrative staff at the Institute of Genetics and Biological Research Centre.

I appreciate the friendship and the opportunity to spend great time with the ITC members of BRC and those of my hungarian friends who made my stay here memorable.

My deepest gratitude to my family members for their love, understanding and encouragement through out. To my parents and grand parents: Thank you for everything. 


\section{Supplementary material}

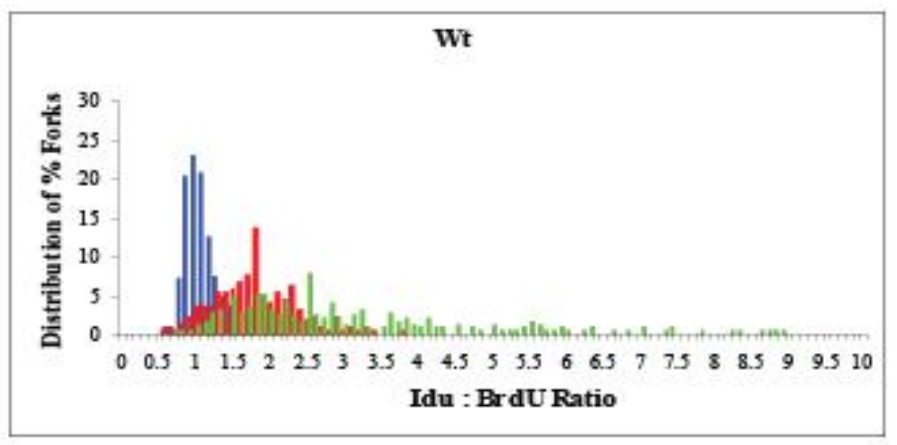

Supplementary Figure 1. Distribution of percentages of replication forks at corresponding $\mathrm{IdU} / \mathrm{BrdU}$ ratios. Blue bars, $0 \mathrm{~J} / \mathrm{m}^{2} \mathrm{UV}-\mathrm{C}$; red bars, 20 $\mathrm{J} / \mathrm{m}^{2} \mathrm{UV}-\mathrm{C}$; green bars, $40 \mathrm{~J} / \mathrm{m}^{2} \mathrm{UV}-\mathrm{C}$.
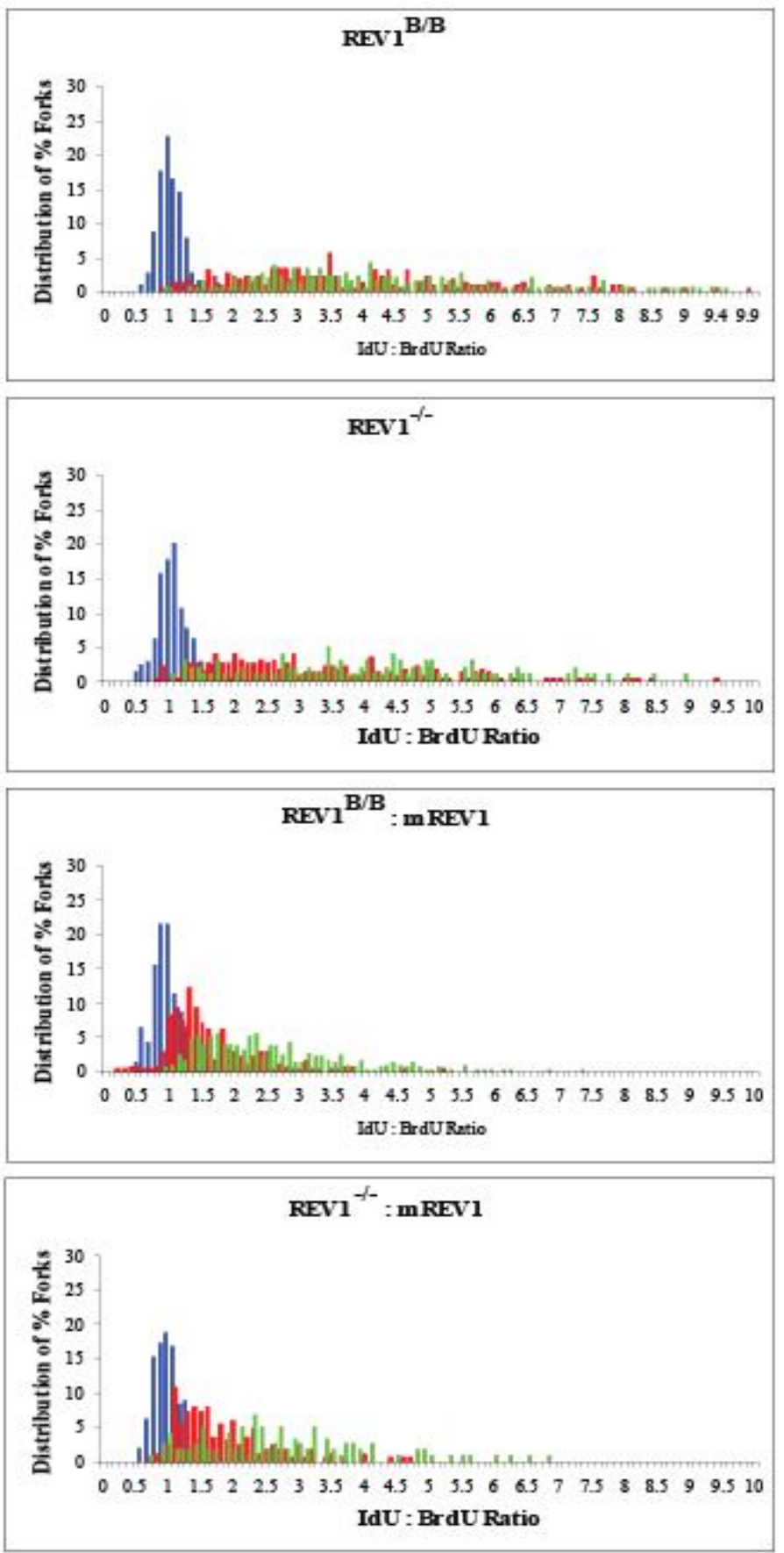


\begin{tabular}{|l|l|}
\hline Primer Sequence & Lysine residue \\
\hline GTTTCAGACTATGAAATGAGGTTGATGGATTTAGATGTTG & K117R Forward \\
\hline CAACATCTAAATCCATCAACCTCATTTCATAGTCTGAAAC & K117R Reverse \\
\hline CAGCTGTGTAGTAAGGATGCCTTCTGGTG & K138R Forward \\
\hline CACCAGAAGGCATCCTTACTACACAGCTG & K138R Reverse \\
\hline GTTGTAATTTCCTGTGCAAGAGACGGAGTGAAATTTTC & K164R Forward \\
\hline GAAAATTTCACTCCGTCTCTTGCACAGGAAATTACAAC & K164R Reverse \\
\hline GGAAATGGAAACATTAGATTGTCACAGACAAG & K181R Forward \\
\hline CTTGTCTGTGACAATCTAATGTTTCCATTTCC & K181R Reverse \\
\hline GACAAGTAATGTCGATAGAGAGGAGGAAGCTG & K190R Forward \\
\hline CAGCTTCCTCCTCTCTATCGACATTACTTGTC & K190R Reverse \\
\hline CCCCTTGTTGTAGAGTATAGAATTGCGGATATGGGACAC & K240R Forward \\
\hline GTGTCCCATATCCGCAATTCTATACTCTACAACAAGGGG & K240R Reverse \\
\hline GATATGGGACACTTACGATACTACTTGGCTCCCAAGAT & K248R Forward \\
\hline TACTTGGGAGCCAAGTAGTATCGTAAGTGTCCCATATC & K248R Reverse \\
\hline CAACTTGGCTCCCAGGATCGAGGATGAAG & K254R Forward \\
\hline CTTCATCCTCGATCCTGGGAGCCAAGTTG & K254R Reverse \\
\hline
\end{tabular}

Supplementary Table 1. Primer sequences used for mutating the lysine residues to respective arginines. 


\section{Summary}

Unrepaired DNA damage blocks the progression of replication by high-fidelity classical DNA polymerases. Known pathway to overcome these replication blocks is translesion synthesis, which is the replicative bypass of DNA damage by low-fidelity non-classical polymerases. For translesion synthesis (TLS) to occur, the non-classical DNA polymerase must be recruited to sites of DNA damage and a polymerase switch must occur between the stalled classical polymerase and the incoming nonclassical polymerase (Pol $\zeta$, Pol $\eta$, Pol, Pol $\kappa$ and Rev1). This switching event is believed to be mediated by the replication accessory factor proliferating cell nuclear antigen (PCNA). The aim of this PhD thesis was a better understanding of the role of translesion synthesis and the role of PCNA in maintaining genome stability. Previous studies have shown that interactions between PCNA and the non-classical polymerase are required for translesion synthesis. Moreover, in response to DNA damage PCNA is monoubiquitylated at Lys-164. This modification of PCNA (Ub-PCNA) is required for translesion synthesis. However, the function of monoubiquitylated PCNA in translesion synthesis remains unknown. It has been postulated that the Ubiquitin Binding Domain mediated binding of TLS Pols to the Ub moiety on PCNA is necessary for TLS. To understand the mechanism by which PCNA targets TLS polymerases, I examined the contributions that the PCNA interacting protein (PIP) domain and Ub-binding zinc finger (UBZ) domain of human Pol $\square$ make to its co-localization with PCNA in replication foci. It was proposed recently that Rev1 mediates translesion synthesis by direct extension of stalled replicons but in a ubiquitinated PCNA-independent fashion. To understand the contribution of Rev1 in the regulation of DNA damage bypass in mammalian cells in vivo, I have analyzed progression of replication on damaged DNA in UV-exposed mouse embryonic fibroblasts (MEFs) that were either fully deficient for Rev1 or contained a deletion of the BRCT domain of Rev1. Further I have also investigated replication of UVdamaged DNA templates in mouse embryonic fibroblasts deficient for Rev3, the catalytic subunit of polymerase zeta, which also is involved in translesion synthesis. 
Yeast genetic studies have been instrumental in providing evidence that PCNA monoubiquitylation is required for translesion synthesis and PCNA K63-linked polyubiquitylation governs template switch dependent replication through DNA lesions, whereas modification of PCNA by SUMO prevents recombination and also regulates template switch. In human cells, the significance of mono- and polyubiquitylation of PCNA has been demonstrated; the SUMOylation of PCNA has not been confirmed, raising doubts as to the conservation of SUMO-PCNA dependent mechanisms. Therefore, I have tested the SUMOylation of PCNA in human cells and investigated the role of SUMO modification of human PCNA.

During the course of my doctoral research I was able to show that the mutational inactivation of the UBZ domain does not impair the co-localization of hPol $\eta$ with PCNA in replication foci in UV-irradiated cells, however, hPol ๆ's binding to PCNA via its PIP domain is essential for its ability to access PCNA in replication foci. I provide evidence for the role of Rev1 in immediate lesion bypass mediated by the BRCT domain of Rev1. Unlike Rev1, Rev3 appears not to be involved in immediate translesion synthesis at a stalled replication fork. Also I was able to detect the SUMOylation of PCNA in human cells and show that SUMO modification of human PCNA lowers the rate of recombination. These studies offer mechanistic insights into the role of translesion synthesis polymerases Pol $\eta$, Rev1 and Rev3 of Polל and prove the conservation of yeast SUMO-PCNA dependent mechanisms in human cells. 


\section{1. Összefoglalás}

A kijavítatlan DNS károsodások feltartóztatják a nagy hüséggel másoló klasszikus DNS polimerázokat. Ennek a replikációs blokknak ismert feloldási mechanizmusa a transzléziós szintézis (TLS), amely valójában a károsodásnak a replikáció során történő elkerülése, melyet alacsony másolási hüségü, nem-klasszikus polimerázok végeznek. Ahhoz, hogy a transzléziós szintézis megtörténhessen, a nem-klasszikus DNS polimeráznak a DNS károsodás helyére kell jutnia és polimeráz csere során az

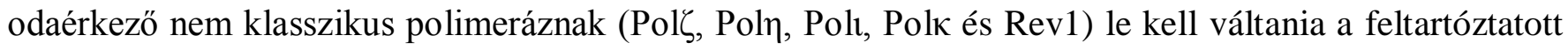
klasszikus polimerázt. Ezt a lecserélődési folyamatot a járulékos replikációs faktorként ismert proliferáló sejt nukleáris antigén (PCNA) közvetíti.

PhD tézisem célja a transzléziós szintézis szerepének, valamint a PCNA genom stabilitást fenntartó funkciójának jobb megértése volt. Előzetes vizsgálatok azt mutatták, hogy a transzléziós szintézishez a PCNA molekula és a nem-klasszikus polimerázok kölcsönhatása szükséges. Ezenkívül, a DNS károsodásra adott válasz részeként, a PCNA a Lys-164 pozícióban monoubikvitinálódik és ez a posztranszlációs módosítás (Ub-PCNA) feltétele a transzléziós szintézisnek. A monoubikvitinált PCNA szerepe a transzléziós szintézisben jelenleg nem tisztázott. Feltételezik, hogy a TLS polimerázok Ubikvitin Kötő Doménje és a PCNA Ub módosulás közötti kötés szükséges a TLS-hez. Hogy megérthessük a mechanizmusokat, amelyekkel a PCNA célba juttatja a TLS polimerázokat, megvizsgáltam hogy a Pol $\eta$ PIP (PCNA interacting) és UBZ (UB-binding zinc finger) doménjei szerepet játszanak-e a Pol $\eta$ és a PCNA replikációs fókuszokban történő co-lokalizációjában. A közelmúltban ismerték fel, hogy a Rev1 ubikvitinált PCNA függő módon a feltartóztatott replikonok közvetlen extenziójával járul hozzá a transzléziós szintézishez. Hogy megérthessük a Rev1 szerepét az emlős sejtekben in vivo végbemenő DNS károsodás elkerülési mechanizmusok szabályozásában a replikáció előrehaladását vizsgáltam károsodott DNS-en, azaz olyan UV sugárzásnak kitett egér embrionális fibroblaszt (MEF) sejtekben, amelyekből vagy teljesen hiányzott a Rev1 vagy deléciót hordoztak a Rev1 
BRCT doménjében. Ezenkívül szintén megvizsgáltam az UV-károsodást hordozó DNS templát replikációját olyan egér embrionális fibroblaszt sejtekben, amelyekben hibás volt a Rev3 fehérje, ami a transzléziós szintézisben szintén szerepet játszó polimeráz zeta katalitikus alegysége.

Az élesztő fajokon végzett genetikai vizsgálatok rendkívül hasznosnak bizonyultak annak bizonyításában, hogy a PCNA monoubiquitinálása szükséges a transzléziós szintézishez, a PCNA K63kapcsolt poliubikvitinálása vezérli a templát váltás függő replikációt a károsodott DNS-en, míg a PCNA molekula SUMO módosítása gátolja a rekombinációt és szintén részt vesz a templát váltás szabályozásában. Emberi sejtekben a PCNA mono- és poliubiquitinációjának jelentősége bizonyítást nyert, a PCNA SUMOilációját mindeddig nem erősítették meg, megkérdőjelezve a a SUMO-PCNA függő mechanizmusok konzerváltságát. Ezért teszteltem a PCNA SUMOilációját emberi sejtekben és megvizsgáltam az emberi PCNA SUMO módosításának szerepét.

PhD kutatásaim során kimutattam, hogy az UBZ domén inaktivációja nem csökkenti a hPoln colokalizációját a PCNA-val a replikációs fókuszokban UV-kezelt sejteken, azonban a hPol $\eta$ PIP doménen keresztül való kötődése PCNA-hez elengedhetetlenül szükséges a hPoln és a PCNA kölcsönhatásához replikációs fókuszokban. Bizonyítottam a Rev1 szerepét az azonnali károsodás elkerülésben, melyet a Rev1 BRCT doménje közvetít. Eltérően a Rev1-től, a Rev3 nagy valószínüséggel nem vesz részt az azonnali transzléziós szintézisben a feltartóztatott replikációs villában. Ezenkívül sikerült kimutatnom a PCNA SUMOiláció létezését emberi sejtekben és igazoltam, hogy a human PCNA SUMO-módosítása csökkenti a rekombináció gyakoriságát. Ezek a vizsgálatok betekintést nyújtanak a Pol $\eta$, Rev1 valamint a a Pol $\zeta$ (alegysége a Rev3) transzléziós polimerázok müködésébe és bizonyítják az élesztőben leírt SUMO-PCNA függő mechanizmusok konzerváltságát és létezését emberi sejtekben. 